\title{
Uranium Neutron Coincidence Collar Model Utilizing Boron-10 Lined Tubes
}

Jeremy L. Rogers

James H. Ely

Richard T. Kouzes

Azaree T. Lintereur

Edward R. Siciliano

September 2012

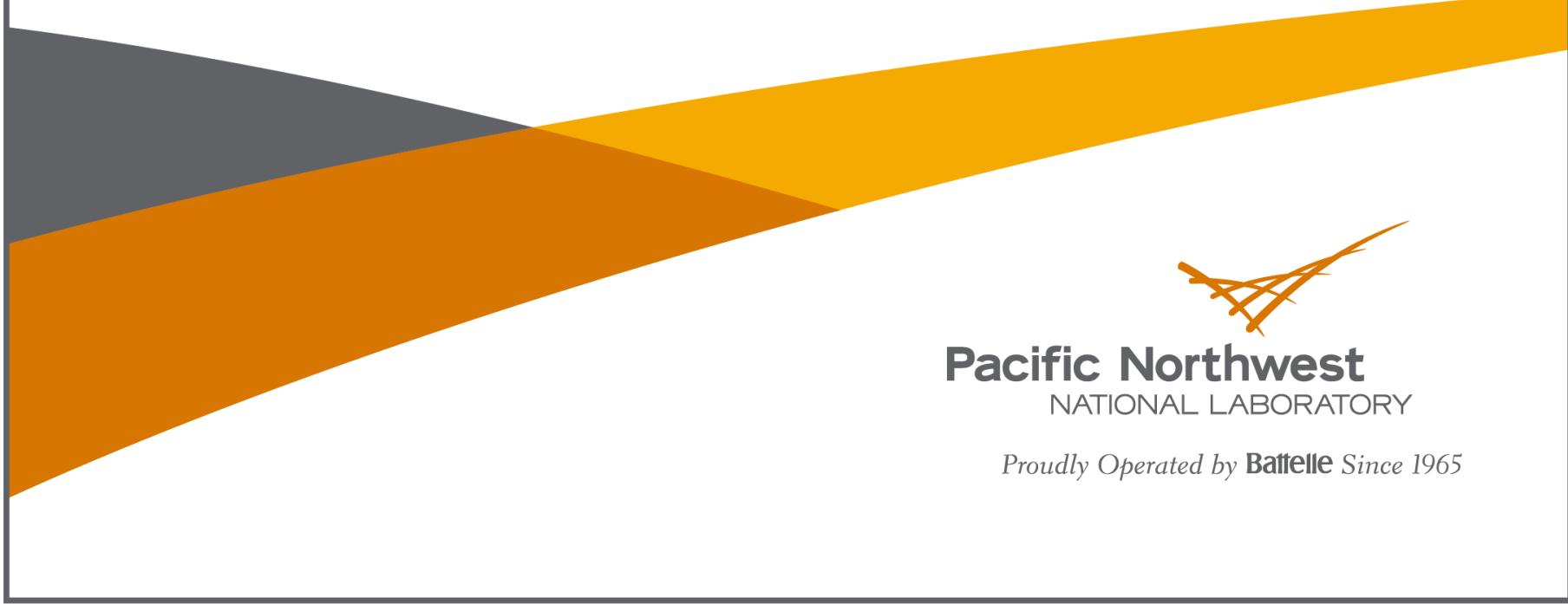




\title{
DISCLAIMER
}

This report was prepared as an account of work sponsored by an agency of the United States Government. Neither the United States Government nor any agency thereof, nor Battelle Memorial Institute, nor any of their employees, makes any warranty, express or implied, or assumes any legal liability or responsibility for the accuracy, completeness, or usefulness of any information, apparatus, product, or process disclosed, or represents that its use would not infringe privately owned rights. Reference herein to any specific commercial product, process, or service by trade name, trademark, manufacturer, or otherwise does not necessarily constitute or imply its endorsement, recommendation, or favoring by the United States Government or any agency thereof, or Battelle Memorial Institute. The views and opinions of authors expressed herein do not necessarily state or reflect those of the United States Government or any agency thereof.

\author{
PACIFIC NORTHWEST NATIONAL LABORATORY \\ operated by \\ BATTELLE \\ for the \\ UNITED STATES DEPARTMENT OF ENERGY \\ under Contract DE-AC05-76RL01830
}

Printed in the United States of America

\section{Available to DOE and DOE contractors from the \\ Office of Scientific and Technical Information, \\ P.O. Box 62, Oak Ridge, TN 37831-0062; \\ ph: (865) 576-8401 \\ fax: (865) 576-5728 \\ email: reports@adonis.osti.gov}

Available to the public from the National Technical Information Service, U.S. Department of Commerce, 5285 Port Royal Rd., Springfield, VA 22161

ph: (800) 553-6847

fax: (703) 605-6900

email: orders@ntis.fedworld.gov

online ordering: http://www.ntis.gov/ordering.htm 


\section{Uranium Neutron Coincidence Collar Model Utilizing Boron-10 Lined Tubes}

Jeremy L. Rogers

James H. Ely

Richard T. Kouzes

Azaree T. Lintereur

Edward R. Siciliano

September 2012

Pacific Northwest National Laboratory

Richland, Washington 99352 


\section{Executive Summary}

The Department of Energy Office of Nuclear Safeguards and Security (NA-241) is supporting the project Coincidence Counting With Boron-Based Alternative Neutron Detection Technology at Pacific Northwest National Laboratory (PNNL) for the development of a ${ }^{3} \mathrm{He}$ proportional counter alternative neutron coincidence counter. The goal of this project is to design, build and demonstrate a system based upon ${ }^{10} \mathrm{~B}$-lined proportional tubes in a configuration typical for ${ }^{3} \mathrm{He}-$ based coincidence counter applications. This report, providing results for model development of Alternative Boron-Based Uranium Neutron Coincidence Collar (ABUNCL) designs, is a deliverable under Task 2 of the project.

Several configurations of the ABUNCL models, which use ${ }^{10} \mathrm{~B}$-lined proportional counters in place of ${ }^{3} \mathrm{He}$ proportional counters for the neutron detection element, are discussed. Direct replacement of the ${ }^{3} \mathrm{He}$ tubes with an equal number of ${ }^{10} \mathrm{~B}$-lined tubes resulted in a considerable decrease in efficiency $(\boldsymbol{\varepsilon})$ and increase in the die-away time $(\tau)$, as expected. Depending on the Uranium Neutron Coincidence Collar (UNCL) configuration calculated, the coincidence figure of merit of performance $\left(\mathrm{FOM}=\varepsilon^{2} / \tau\right)$ of the direct-replacement ABUNCLs was $2.8-3.3 \%$ that of the corresponding UNCL configuration.

Increasing the active length of the ${ }^{10} \mathrm{~B}$-lined tubes and the height of the HDPE assembly resulted in a $44 \%$ increase in the FOM (from 0.14 to 0.25 ) over the corresponding direct-replacement ABUNCL.

Expanding the HDPE assembly to use five rows of ${ }^{10} \mathrm{~B}$-lined tubes with an assumed $0.75 \mu \mathrm{m}{ }^{10} \mathrm{~B}$ metal lining improved the FOM to 3.1, though this improvement was not enough to match the FOM of the ${ }^{3} \mathrm{He}$-based UNCL (4.2). Using models with thicker ${ }^{10} \mathrm{~B}$ metal linings improved the model FOM considerably, to a maximum of 5.1 using a $2.0 \mu \mathrm{m}{ }^{10} \mathrm{~B}$ metal lining. Since the lining thickness and composition are kept proprietary to GE Reuter-Stokes, no information on the actual lining was used for this study. The $0.75 \mu \mathrm{m}{ }^{10} \mathrm{~B}$ metal lining was chosen as the model basis in previous work based solely upon the agreement that value gave for comparison of modeled total count efficiencies to measured efficiencies of the systems modeled.

Future work on this project will include using a shift register to measure singles capture rates for comparison to modeled efficiencies and doubles capture rate to deduce effective die-away times for banks of multiple ${ }^{10} \mathrm{~B}$-lined tubes. These measurements will be made to validate these characteristics in models, which will be applied to the complete ABUNCL model before the construction a full-scale prototype. These validations will determine whether updating the ${ }^{10} \mathrm{~B}$ lining thickness and or/composition in the model basis is necessary to better simulate the actual performance characteristics of a ${ }^{10} \mathrm{~B}$-based ABUNCL system. 


\section{Acronyms and Abbreviations}

$\begin{array}{ll}\text { AmLi } & \text { Americium-lithium neutron source } \\ \text { DOE } & \text { U.S. Department of Energy } \\ \varepsilon & \text { Detection efficiency } \\ \text { FOM } & \text { Figure of Merit } \\ \text { GE } & \text { General Electric } \\ \text { HDPE } & \text { High Density Polyethylene } \\ \text { IAEA } & \text { International Atomic Energy Agency } \\ \text { LEC } & \text { Low-Energy Cutoff } \\ \text { MCA } & \text { Multi-Channel Analyzer } \\ \text { MOX } & \text { Mixed Oxide fuel } \\ \text { PHL } & \text { Pulse-Height Light } \\ \text { PNNL } & \text { Pacific Northwest National Laboratory } \\ \text { Pu } & \text { Plutonium } \\ \text { PVT } & \text { Polyvinyl Toluene } \\ \tau & \text { Die-away time } \\ \text { U } & \text { Uranium } \\ \text { UNCL } & \text { Uranium Neutron Coincidence Collar }\end{array}$




\section{Contents}

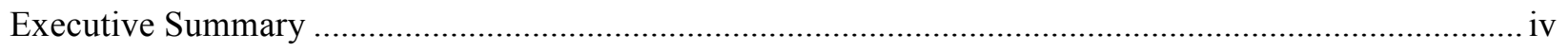

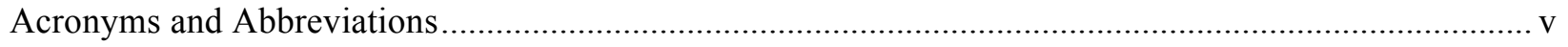

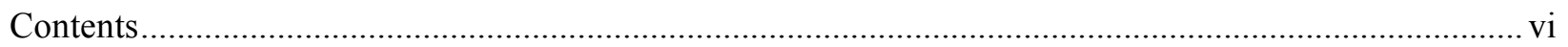

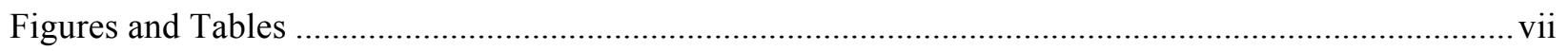

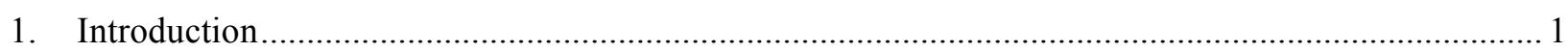

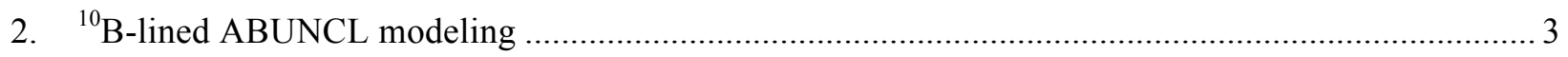

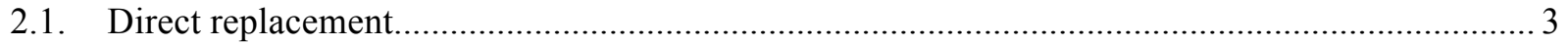

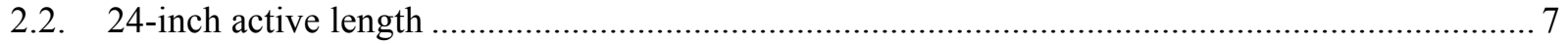

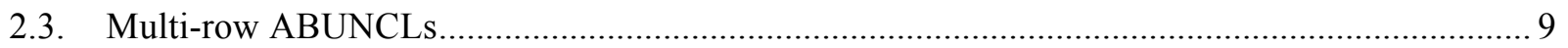

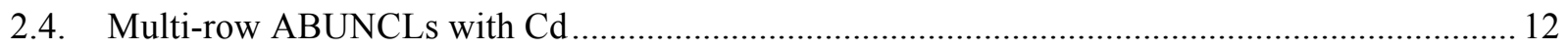

2.5. HDPE Assembly Modifications with Multi-row ABUNCLs................................................... 14

2.6. Multi-row ABUNCLs with Alternative Moderating Materials ................................................. 17

2.7. Effect of Boron Lining Thickness on Multi-row ABUNCLs.................................................... 18

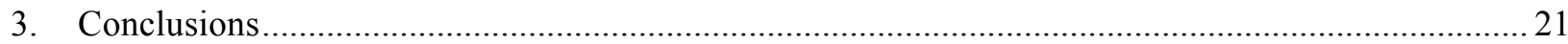

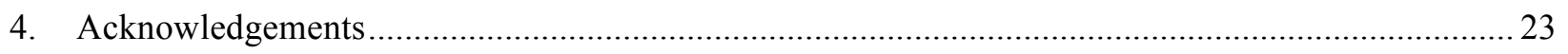

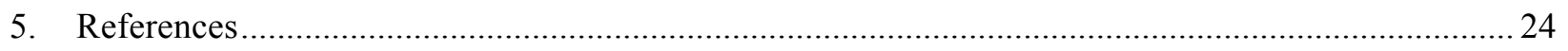




\section{Figures and Tables}

\section{Figures}

Figure 2.1. Top and side views of ${ }^{10} \mathrm{~B}$-lined tubes placed directly into the active UNCL-II BWR model. The ${ }^{10} \mathrm{~B}$ lining is not visible at this resolution. ........................................................................ 3

Figure 2.2. Results for active ABUNCL-II BWR die-away time computed with the model. .................... 6

Figure 2.3. Scatter plot of FOM values for the active UNCL-II BWR configuration with ${ }^{3} \mathrm{He}$ and ${ }^{10} \mathrm{~B}$-lined tubes.

Figure 2.4. Comparison of the ABUNCL HDPE banks using 32.2-cm (12.7-inch) active length (left) and 61.0-cm (24-inch) active length ${ }^{10} \mathrm{~B}$-lined tubes (right).

Figure 2.5. Comparison of the ABUNCL HDPE source blocks using source block with original (left) and scaled dimensions (right). 8

Figure 2.6. Comparison of 3-row ABUNCLs with staggered (left) and aligned rows (right).................. 10

Figure 2.7. Comparison of 5-row ABUNCLs with staggered (left) and aligned rows (right)................... 10

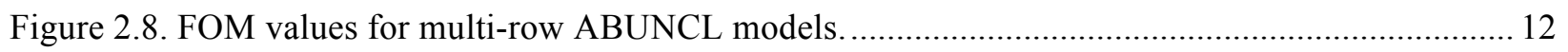

Figure 2.9. FOM values for aligned-row models with 0.4-mm Cd liner on inside of fuel cavity............. 13

Figure 2.10. FOM values for aligned-row models with 0.4-mm Cd liner on outside of HDPE assembly. 13

Figure 2.11. FOM values for variations in the HDPE leading edge with trailing edge at constant $2.22 \mathrm{~cm}$.

Figure 2.12. FOM values for variations in the HDPE trailing edge with leading edge at constant $1.27 \mathrm{~cm}$.

Figure 2.13. Top view of 5-row close-packed model. ......................................................................... 16

Figure 2.14. FOM values showing effects for 4-row and 5-row close-packing..................................... 16

Figure 2.15. Top view of ABUNCL with tube moderator replaced with polyvinyl toluene. .................... 17

Figure 2.16. FOM values showing effect of replacing HDPE by PVT as moderator in selected ABUNCL

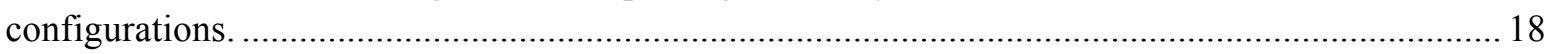

Figure 2.17. FOM values for various ${ }^{10} \mathrm{~B}$ metal lining thicknesses in 5-aligned-row, 95-tube ABUNCL

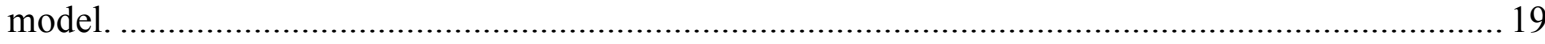

Figure 2.18. Effect of ${ }^{10} \mathrm{~B}$ lining thickness on n-capture reactions, count efficiency, and die-away time in

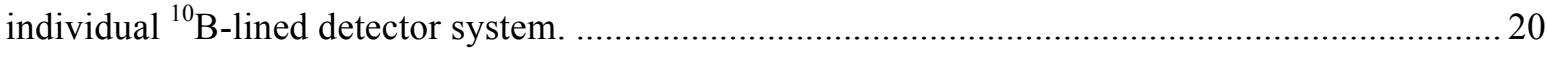

\section{Tables}

Table 1.1. Characteristics of the ${ }^{3} \mathrm{He}$-based UNCL-II BWR active coincidence counter configuration. ...... 1

Table 2.1. Comparison of ${ }^{10} \mathrm{~B}$-lined as direct replacement for ${ }^{3} \mathrm{He}$ tubes in eight UNCL configurations. ... 4

Table 2.2. ABUNCL die-away time values calculated using two tally methods.......................................5

Table 2.3. Results for ABUNCL models using $61 \mathrm{~cm}{ }^{10} \mathrm{~B}$-lined tubes in place of $32 \mathrm{~cm}$ tubes................ 9 
Table 2.4. Results for multi-row ABUNCL baseline models using staggered and aligned rows.............. 11

Table 2.5. Effect of ${ }^{10} \mathrm{~B}$ lining thickness on efficiency, die-away time, FOM in 5-aligned-row, 95-tube

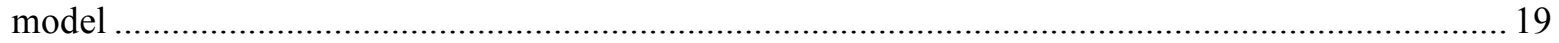




\section{Introduction}

The search for technological alternatives to ${ }^{3} \mathrm{He}$ is a major research area in nuclear security and safeguards due to the shortage of this gas in recent years [Kouzes 2010; Menlove 2011]. One of the important safeguards applications of ${ }^{3} \mathrm{He}$ has been for coincidence counting instruments. Coincidence counting is a high-precision technique used to measure the mass of plutonium $(\mathrm{Pu})$ or uranium (U) in samples for safeguards applications [PANDA 1991]. For example, the Uranium Neutron Coincidence Collar (UNCL) is used by the International Atomic Energy Agency (IAEA) for verification of the mass of ${ }^{235} \mathrm{U}$ in low-enriched $\mathrm{U}$ fuel assemblies [Menlove 1981; Menlove 1990].

Coincidence counters fall into one of two main categories, passive and active. Passive coincidence counters are used for both fresh and spent $\mathrm{Pu}$-based [mixed oxide (MOX)] fuels, as well as fuel processing, where plutonium accountancy is the objective. Active coincidence counting, where an external neutron source (usually an americium-lithium [AmLi] $(\alpha, n)$ source) is used to induce fission in the sample being assayed, is used for U-based fresh fuels [Kouzes 2012]. Various designs of the UNCL-I [Menlove 1981] and UNCL-II [Menlove 1990; Croft 2011] exist for application to boiling water reactor (BWR) and pressurized water reactor (PWR) fuel, consisting of either three or four banks of detectors surrounding a central cavity where the fuel assembly is placed during measurements. The UNCL thus has eight different configurations: UNCL-I or UNCL-II, PWR or BWR, active or passive [Siciliano 2012b].

The active UNCL-II BWR was chosen as the target coincidence counter for further study. Table 1.1 shows characteristics of the active UNCL-II BWR detector that utilizes ${ }^{3} \mathrm{He}$ proportional tubes, as reported in a previous study [Siciliano 2012b]. The number of ${ }^{3} \mathrm{He}$ tubes used in the assembly is shown, along with the corresponding moles of gas. All ${ }^{3} \mathrm{He}$ tubes used in these assemblies have a $2.54 \mathrm{~cm}$ (1") outer diameter, a $33 \mathrm{~cm}$ (13") active length, and are filled with four atmospheres of ${ }^{3} \mathrm{He}$ (assumed $22.5^{\circ} \mathrm{C} / 68^{\circ} \mathrm{F}$ ). The aluminum clad tubes are GE Reuter Stokes model \# RS-P4-2813-107. The dimensions shown are the height (H), length (L) and width (W) of the fuel cavity. The total count efficiency $(\varepsilon)$, die away time $(\tau)$ and Figure of Merit (FOM), computed as $\varepsilon^{2} / \tau$ [Henzlova 2010; Henzlova 2012], are shown. The efficiency is measured with a

${ }^{252} \mathrm{Cf}$ source in the center of the fuel cavity. The model results shown are from [Siciliano 2012b]. The efficiency of the active UNCL-II BWR configuration is seen in the table to be about $15.4 \%$, with a die away time of $58 \mu$ s and a FOM of 4.0 (in units of $\%{ }^{2} / \mu \mathrm{s}$ ) [Croft 2011].

Table 1.1. Characteristics of the ${ }^{3} \mathrm{He}-\mathrm{based}$ UNCL-II BWR active coincidence counter configuration.

\begin{tabular}{|c|c|c|c|c|c|c|c|}
\hline Detector & $\begin{array}{l}\text { Total \# Tubes, } \\
\text { Configuration, \& } \\
\text { Moderator/EC } \\
\text { Changes } \\
\text { H x L x W } \\
\end{array}$ & $\begin{array}{l}\text { Total } \\
\text { No. } \\
\text { Moles }\end{array}$ & $\begin{array}{l}\text { Total-Count } \\
\text { Efficiency }(\varepsilon)\end{array}$ & $\begin{array}{l}\text { Die- } \\
\text { Away } \\
\text { Time } \\
(\tau) \mu s\end{array}$ & $\begin{array}{l}\text { FOM } \\
=\varepsilon^{2} / \tau, \text { in } \\
\text { units of } \\
(\%)^{2} / \mu \mathrm{s}\end{array}$ & $\begin{array}{l}\text { Model } \\
\text { Total- } \\
\text { Count } \\
\text { Efficiency } \\
(\varepsilon) \\
\end{array}$ & $\begin{array}{l}\text { Model } \\
\text { Die- } \\
\text { Away } \\
\text { Time } \\
(\tau) \mu s \\
\end{array}$ \\
\hline $\begin{array}{l}\text { UNCL-II } \\
\text { Active } \\
\text { BWR }\end{array}$ & $\begin{array}{l}16 \text { tubes } \\
3 \text { Rectangular slabs } \\
41.3 \times 16.5 \times 16.5 \mathrm{~cm}\end{array}$ & 0.39 & $\begin{array}{l}15.3 \% * \\
15.4 \% * * \\
13.5 \%( \pm 10 \%)^{\#}\end{array}$ & $58 *$ & 4.0 & $14.9 \%$ & 53 \\
\hline
\end{tabular}


Detectors for safeguards applications require high efficiency and well differentiated gamma ray and neutron signals. ${ }^{10} \mathrm{~B}$-lined proportional counters were chosen as the technology to be used in this design effort for an alternative-based UNCL. These proportional counters are a direct physical replacement for ${ }^{3} \mathrm{He}$ tubes, do not contain hazardous materials, and have equivalent gamma ray insensitivity as ${ }^{3} \mathrm{He}$ tubes, but they have lower neutron detection efficiency than ${ }^{3} \mathrm{He}$ tubes. This is because ${ }^{10} \mathrm{~B}$ has a smaller neutron capture cross-section than ${ }^{3} \mathrm{He}$ and not all the ${ }^{10} \mathrm{~B}$ reaction products escape from the lining to be counted in the proportional gas.

General Electric (GE) Reuter-Stokes (Twinsburg, $\mathrm{OH}$ ) has developed multi-tube arrays of ${ }^{10} \mathrm{~B}$ lined tubes that show performance comparable to one ${ }^{3} \mathrm{He}$ tube, and can provide tubes in a variety of geometries. Testing has been performed at PNNL on the GE tubes [Lintereur 2010; Lintereur 2012]. The modeling for this project was performed using variations of the ${ }^{10} \mathrm{~B}$-lined proportional counter technology manufactured by GE Reuter-Stokes.

Under this project, Pacific Northwest National Laboratory (PNNL) has delivered a number of reports on coincidence counting, including an overview [Kouzes 2012], model validation [Lintereur 2012; Rogers 2012], wall effect models [Siciliano 2012], and models of ${ }^{3} \mathrm{He}-$ based UNCL systems [Siciliano 2012b]. This report discusses simulation results of coincidence counters designed with ${ }^{10} \mathrm{~B}$-lined proportional counters in place of ${ }^{3} \mathrm{He}$ proportional counters. A modeling study of the Alternative Boron-Based Uranium Neutron Coincidence Collar (ABUNCL), a modification of the UNCL, is presented. Both direct replacements of the ${ }^{3} \mathrm{He}$ tube with ${ }^{10} \mathrm{~B}$-lined tubes in current UNCL models and expansions of current UNCL models using multiple rows of ${ }^{10} \mathrm{~B}$-lined proportional counters are discussed. 


\section{2. ${ }^{10} \mathrm{~B}$-lined ABUNCL modeling}

Previous work at PNNL modeled the eight configurations of the ${ }^{3} \mathrm{He}$-based UNCL coincidence counter [Siciliano 2012b]. For consistency with those results, all model evaluations reported in this paper had the detector systems resting on a thin aluminum table $65.9 \mathrm{~cm}$ above a concrete floor. The efficiencies and die-away times calculated by the models using a ${ }^{252} \mathrm{Cf}$ source centered in the detector volume agreed to within $10 \%$ of measured values for the corresponding systems, where measured data was available.

\subsection{Direct replacement}

The first step in the design development of a boron-based coincidence counter was to directly replace the $2.54-\mathrm{cm}(1$-inch $){ }^{3} \mathrm{He}$ tubes in the UNCL models with $2.54-\mathrm{cm}$ (1-inch) ${ }^{10} \mathrm{~B}$-lined tubes of equal length (see Figure 2.1). The ${ }^{10} \mathrm{~B}$-lined coincidence counter models were built in MCNPX 2.7.0 [Pelowitz 2011]. These models are referred to as Alternative Boron-based Uranium Neutron Coincidence Collars (ABUNCL).

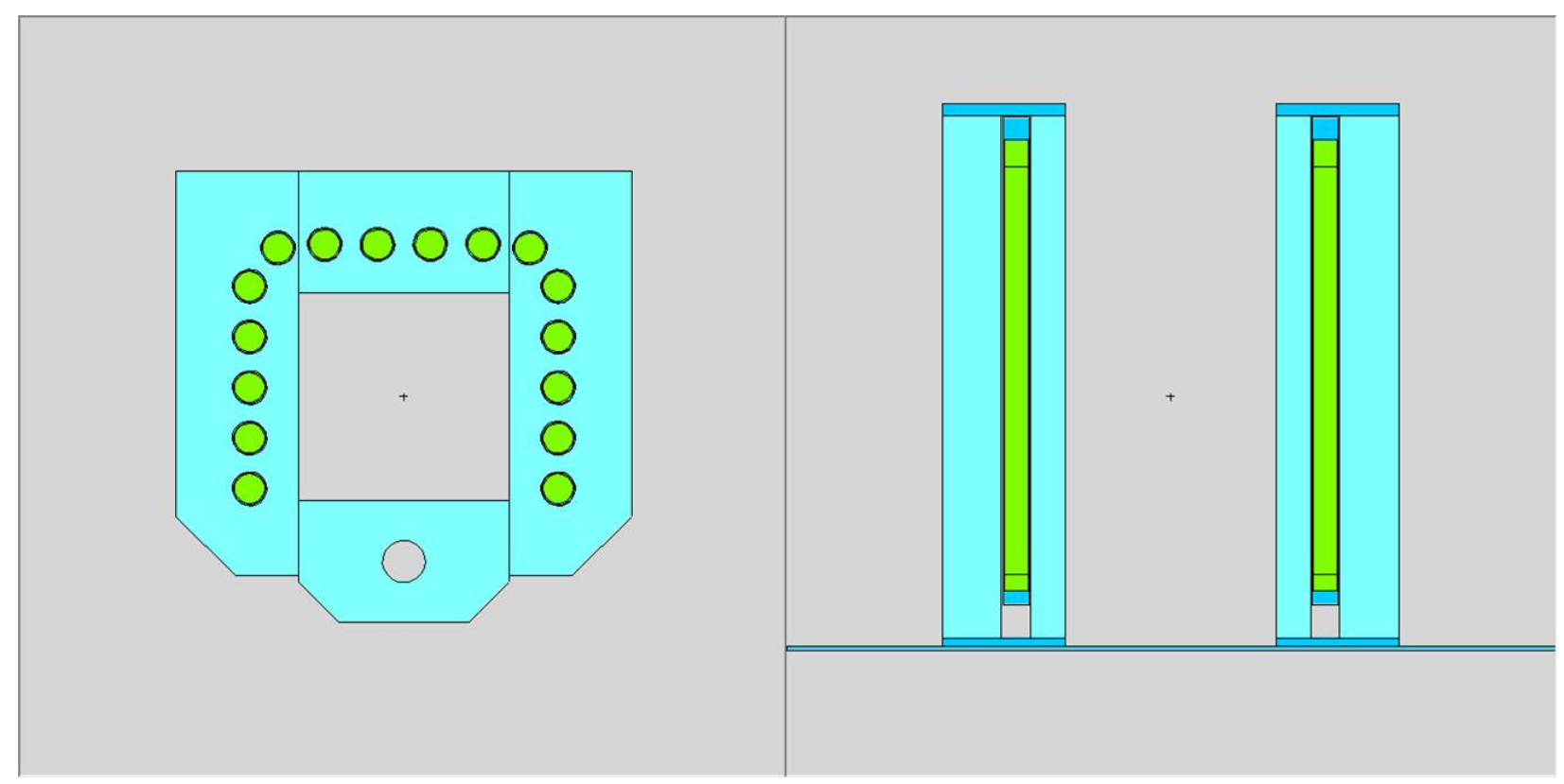

Figure 2.1. Top and side views of ${ }^{10} \mathrm{~B}$-lined tubes placed directly into the active UNCL-II BWR model. The ${ }^{10} \mathrm{~B}$ lining is not visible at this resolution.

The ${ }^{10} \mathrm{~B}$-lined tubes used in the model were modified versions of the GE RS-B1-0824-101 detector model, as discussed in previous reports [Kouzes 2012; Rogers 2012]. Since this detector model has a 60.1-cm (24-inch) active length and the UNCL uses a 33.0-cm (13-inch) active length ${ }^{3} \mathrm{He}$ tube, the ${ }^{10} \mathrm{~B}$-lined active volume was reduced to fit the UNCL system. The dead zones of the shortened ${ }^{10} \mathrm{~B}$-lined tube were assumed to be equivalent to the longer models, and the active volume was scaled to $32.2-\mathrm{cm}(12.7-\mathrm{inch})$, slightly smaller than the ${ }^{3} \mathrm{He}$ active volume it replaced. This difference in active length was due to differences in the construction of the ${ }^{3} \mathrm{He}$ and ${ }^{10}$ B-lined tubes. GE Reuter Stokes only manufactures ${ }^{10} \mathrm{~B}$-lined tubes with whole-inch active 
lengths; this modeled detector represents a modified version of a GE Reuter Stokes detector that fits directly into the existing UNCL system without modification of the HDPE assembly.

All modeled tubes contained a $0.75 \mu \mathrm{m}$ boron metal lining to emulate the total count performance of the measured and validated ${ }^{10} \mathrm{~B}$-lined tubes [Lintereur 2012].

The results for the direct-replacement ABUNCL models are shown in Table 2.1. Though the efficiency values for no low-energy cutoff (LEC) and an LEC of $100 \mathrm{keV}$ are both shown, the FOM was calculated using only the no-LEC efficiency value. Each ${ }^{10} \mathrm{~B}$-lined model's no-LEC efficiency value was calculated to be $\sim 33 \%$ of the corresponding ${ }^{3} \mathrm{He}$ model efficiency value. Thus, to match the efficiency of the ${ }^{3} \mathrm{He}$-based UNCL models, the boron-based ABUNCLs would require at least three rows of ${ }^{10} \mathrm{~B}$-lined tubes. The model efficiencies were evaluated using the sum of the MCNPX F8 pulse-height tallies for the $\alpha$ and Li reaction products and confirmed using the MCNPX F6 energy deposition tallies.

Table 2.1. Comparison of ${ }^{10} \mathrm{~B}$-lined as direct replacement for ${ }^{3} \mathrm{He}$ tubes in eight $\mathrm{UNCL}$ configurations.

\begin{tabular}{|c|c|c|c|c|c|c|c|c|c|c|}
\hline \multirow{3}{*}{ Detector } & \multirow{3}{*}{$\begin{array}{c}\text { Total \# Tubes, } \\
\text { Configuration, \& } \\
\text { Fuel Cavity } \\
\text { H x L x W (cm) }\end{array}$} & \multicolumn{9}{|c|}{ Efficiency $(\varepsilon)$, Die-Away Time $(\tau) \&$ FOM $=\varepsilon^{2} / \tau$} \\
\hline & & \multicolumn{4}{|c|}{ UNCL* } & \multicolumn{5}{|c|}{ ABUNCL } \\
\hline & & $\begin{array}{c}\text { No. } \\
\text { Moles } \\
{ }^{3} \mathrm{He}\end{array}$ & $\varepsilon$ & $\begin{array}{c}\tau \\
(\mu s)\end{array}$ & $\begin{array}{c}\text { FOM } \\
(\%)^{2} / \mu S\end{array}$ & $\begin{array}{c}\text { No. } \\
\text { Moles } \\
{ }^{10} \mathrm{~B}\end{array}$ & $\begin{array}{c}\varepsilon \\
(\mathrm{No} \\
\text { LEC) }\end{array}$ & $\begin{array}{c}\varepsilon \\
(100 \\
\text { keV) }\end{array}$ & $\begin{array}{c}\text { Avg. } \\
\tau \\
(\mu s)\end{array}$ & $\begin{array}{c}\text { FOM } \\
(\text { No LEC) } \\
(\%)^{2} / \mu \mathrm{s}\end{array}$ \\
\hline $\begin{array}{l}\text { UNCL-I } \\
\text { Active } \\
\text { BWR }\end{array}$ & $\begin{array}{c}18 \text { tubes } \\
3 \text { Rectangular banks, } \\
41.4 \times 16.5 \times 23.4\end{array}$ & 0.44 & $12.5 \%$ & 50 & 3.1 & 0.08 & $4.1 \%$ & $3.8 \%$ & 158 & 0.11 \\
\hline $\begin{array}{l}\text { UNCL-I } \\
\text { Active } \\
\text { PWR }\end{array}$ & $\begin{array}{c}18 \text { tubes } \\
3 \text { Rectangular banks } \\
41.4 \times 23.4 \text { x } 23.4\end{array}$ & 0.44 & $9.0 \%$ & 49 & 1.7 & 0.08 & $2.9 \%$ & $2.7 \%$ & 146 & 0.06 \\
\hline $\begin{array}{l}\text { UNCL-I } \\
\text { Passive } \\
\text { BWR }\end{array}$ & $\begin{array}{c}24 \text { tubes } \\
\text { 4 Rectangular banks } \\
41.4 \times 16.5 \text { x } 23.4\end{array}$ & 0.59 & $16.3 \%$ & 51 & 5.2 & 0.11 & $5.3 \%$ & $5.0 \%$ & 160 & 0.18 \\
\hline $\begin{array}{l}\text { UNCL-I } \\
\text { Passive } \\
\text { PWR }\end{array}$ & $\begin{array}{c}24 \text { tubes } \\
4 \text { Rectangular banks } \\
41.4 \times 23.4 \text { x } 23.4\end{array}$ & 0.59 & $12.4 \%$ & 49 & 3.1 & 0.11 & $4.0 \%$ & $3.7 \%$ & 149 & 0.11 \\
\hline $\begin{array}{l}\text { UNCL-II } \\
\text { Active } \\
\text { BWR }\end{array}$ & $\begin{array}{c}16 \text { tubes } \\
3 \text { Rectangular banks } \\
41.3 \times 16.5 \times 16.5\end{array}$ & 0.39 & $14.9 \%$ & 53 & 4.2 & 0.07 & $5.1 \%$ & $4.7 \%$ & 184 & 0.14 \\
\hline $\begin{array}{l}\text { UNCL-II } \\
\text { Active } \\
\text { PWR } \\
\end{array}$ & $\begin{array}{c}20 \text { tubes } \\
3 \text { Rectangular banks } \\
41.3 \times 23.5 \times 23.5 \\
\end{array}$ & 0.49 & $12.3 \%$ & 53 & 2.9 & 0.09 & $4.1 \%$ & $3.8 \%$ & 179 & 0.09 \\
\hline $\begin{array}{l}\text { UNCL-II } \\
\text { Passive } \\
\text { BWR }\end{array}$ & $\begin{array}{c}20 \text { tubes } \\
\text { 4 Rectangular banks } \\
41.3 \times 16.5 \times 16.5\end{array}$ & 0.49 & $19.2 \%$ & 53 & 7.0 & 0.09 & $6.5 \%$ & $6.1 \%$ & 185 & 0.23 \\
\hline $\begin{array}{l}\text { UNCL-II } \\
\text { Passive } \\
\text { PWR }\end{array}$ & $\begin{array}{c}26 \text { tubes } \\
\text { 4 Rectangular banks } \\
41.3 \times 23.5 \times 23.5\end{array}$ & 0.64 & $16.3 \%$ & 53 & 5.0 & 0.12 & $5.5 \%$ & $5.1 \%$ & 179 & 0.17 \\
\hline
\end{tabular}

* From [Siciliano 2012b] 
The die-away times tended to be a factor of $\sim 3$ larger for the UNCL-I cases, and a factor of 3.33.5 larger for the UNCL-II cases. The die-away time values for the modeled ABUNCL systems in Table 2.1 were calculated using the average of two different tally methods: MCNPX F4 capture tallies and F8 PHL tallies. Each tally sorted the captured neutrons into time bins and recorded the exponential die-away of neutrons after the neutron creation event. The die-away times given by each tally method, and the chi squared between the exponential fit and the model, are shown in Table 2.2. The difference between the two methods is due to differences in how the statistics for each tally are computed; the two tallies tend to converge as more particle histories are run.

Table 2.2. ABUNCL die-away time values calculated using two tally methods.

\begin{tabular}{|c|c|c|c|c|c|c|c|}
\hline Detector & \# Tubes & No. Moles ${ }^{10} \mathrm{~B}$ & $\begin{array}{l}\text { F4 } \tau \\
(\mu \mathrm{s})\end{array}$ & $\chi^{2}$ & $\begin{array}{c}\text { F8 PHL } \\
\tau(\mu \mathrm{s})\end{array}$ & $\chi^{2}$ & $\begin{array}{c}\text { Avg. } \tau \\
(\mu s)\end{array}$ \\
\hline $\begin{array}{l}\text { UNCL-I } \\
\text { Active } \\
\text { BWR }\end{array}$ & 18 & 0.08 & 157 & 0.034 & 160 & 0.034 & 158 \\
\hline $\begin{array}{c}\text { UNCL-I } \\
\text { Active } \\
\text { PWR }\end{array}$ & 18 & 0.08 & 147 & 0.030 & 146 & 0.040 & 146 \\
\hline $\begin{array}{c}\text { UNCL-I } \\
\text { Passive } \\
\text { BWR }\end{array}$ & 24 & 0.11 & 159 & 0.035 & 162 & 0.033 & 160 \\
\hline $\begin{array}{c}\text { UNCL-I } \\
\text { Passive } \\
\text { PWR }\end{array}$ & 24 & 0.11 & 149 & 0.031 & 149 & 0.037 & 149 \\
\hline $\begin{array}{c}\text { UNCL-II } \\
\text { Active } \\
\text { BWR } \\
\end{array}$ & 16 & 0.07 & 186 & 0.031 & 183 & 0.031 & 184 \\
\hline $\begin{array}{l}\text { UNCL-II } \\
\text { Active } \\
\text { PWR }\end{array}$ & 20 & 0.09 & 179 & 0.035 & 180 & 0.043 & 179 \\
\hline $\begin{array}{c}\text { UNCL-II } \\
\text { Passive } \\
\text { BWR }\end{array}$ & 20 & 0.09 & 187 & 0.032 & 184 & 0.031 & 185 \\
\hline $\begin{array}{c}\text { UNCL-II } \\
\text { Passive } \\
\text { PWR }\end{array}$ & 26 & 0.12 & 178 & 0.036 & 181 & 0.041 & 179 \\
\hline
\end{tabular}

Figure 2.2 shows an example of the exponential fits to the model results that predict the die-away time for the boron-based ABUNCL system. The solid line represents the fit to the F4 capture tally in the ${ }^{10} \mathrm{~B}$ lining, and the dashed line represents the fit to the F8 pulse height light tally in the proportional gas. The difference in magnitudes reflects the loss of efficiency from the 
reaction products not escaping the lining. The slightly different slopes of the exponential fits (186 versus $183 \mu \mathrm{s}$ ) are averaged together to produce the die-away time values in Table 2.1.

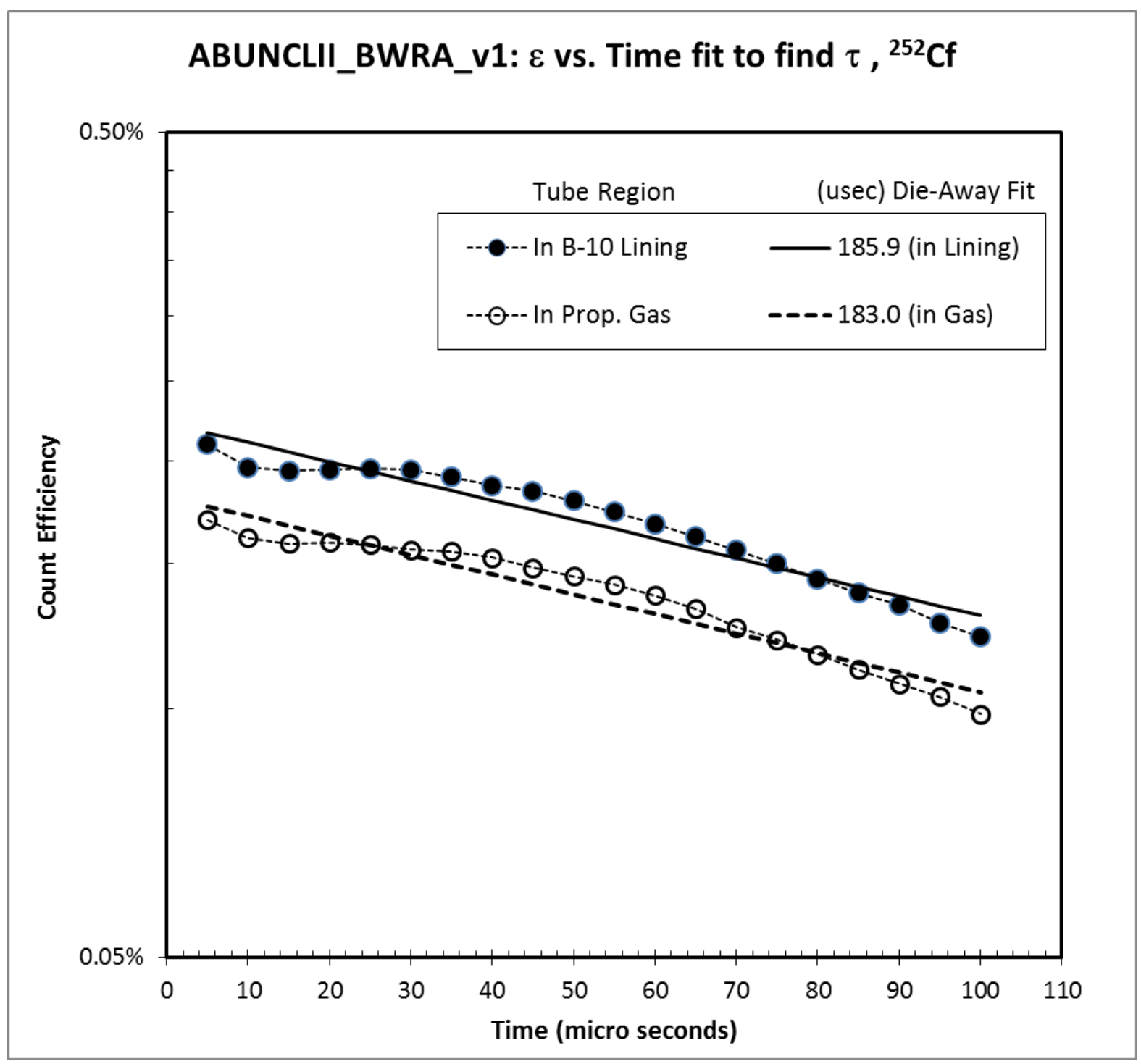

Figure 2.2. Results for active ABUNCL-II BWR die-away time computed with the model.

The figure of merit for the ${ }^{3} \mathrm{He}$ UNCLs and ${ }^{10} \mathrm{~B}$-lined ABUNCLs are pictured in Figure 2.3 by plotting the efficiency versus the die-away time. The ABUNCL model results all cluster at low efficiency (3.8-6.1\%) and long die-away times (179-185 $\mu \mathrm{s})$. The contour lines in Figure 2.3 represent the combinations of efficiency and die-away time where the FOM is constant. Such " $\varepsilon$ $\tau^{\prime \prime}$ scatter plots with contours of constant FOM values provide graphical means of showing progress with respect to the baseline ${ }^{3} \mathrm{He}$ counters, where the target FOM values can be reached by increasing the efficiency, reducing the die-away time, or any combination thereof. In this figure and throughout this report, the FOM values are in units of $\%{ }^{2} / \mu \mathrm{s}$. 


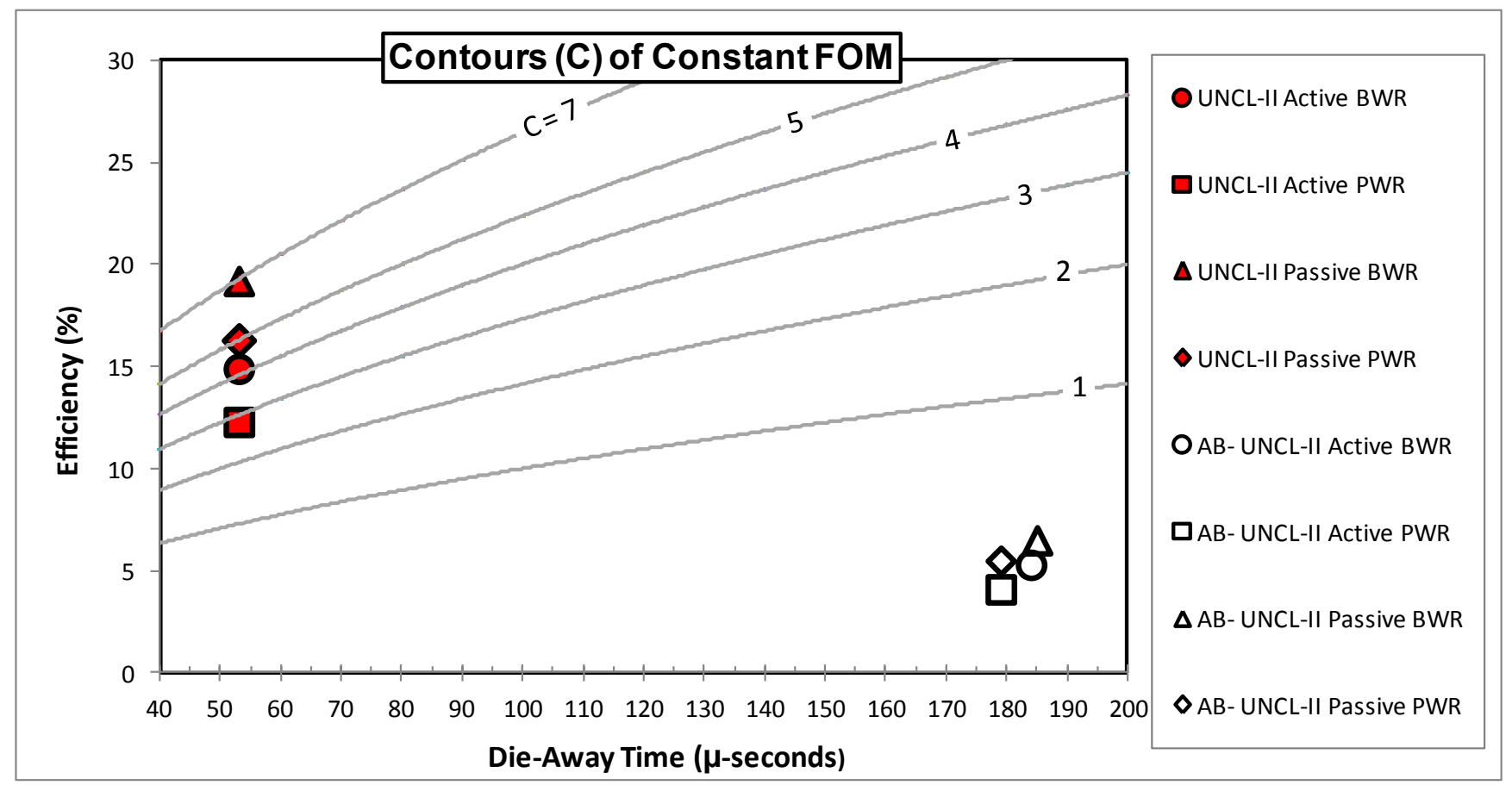

Figure 2.3. Scatter plot of FOM values for the active UNCL-II BWR configuration with ${ }^{3} \mathrm{He}$ and ${ }^{10} \mathrm{~B}$-lined tubes.

\subsection{4-inch active length}

The active ABUNCL-II BWR configuration was chosen as the model for development [Siciliano 2012b]. This configuration was chosen since Los Alamos National Laboratory has a ${ }^{3} \mathrm{He}-$ based system available for test comparison, and it is well documented [Croft et al. 2011]. The 32.2-cm (12.7-inch) active length tubes were replaced with 61.0-cm (24-inch) active length ${ }^{10} \mathrm{~B}$-lined tubes. The 61.0-cm length is a standard GE Reuter-Stokes tube size. The HDPE banks containing the detectors were directly scaled to the height of the ${ }^{10} \mathrm{~B}$-lined tubes, as seen in Figure 2.4 . The HDPE block containing the AmLi source was tested in two configurations, one where the block was the same dimensions as in the smaller assembly, and one where the block dimensions were scaled proportionally to the $61.0-\mathrm{cm}$ active length tubes, as shown in Figure 2.5. The AmLi source is in the same position in both source blocks.

The results for these two models are shown in Table 2.3. For the small source block, the increase in efficiency is enough to offset the increase in the die-away time, resulting in a greater FOM than the corresponding 32.2-cm active length model. The FOM gains small (10\%) incremental increase by using the longer source block, which is reflects more neutrons back into the detector. However, these values are still much less than the FOM of 4.2 for the ${ }^{3} \mathrm{He}$-based UNCL-II BWR system. 


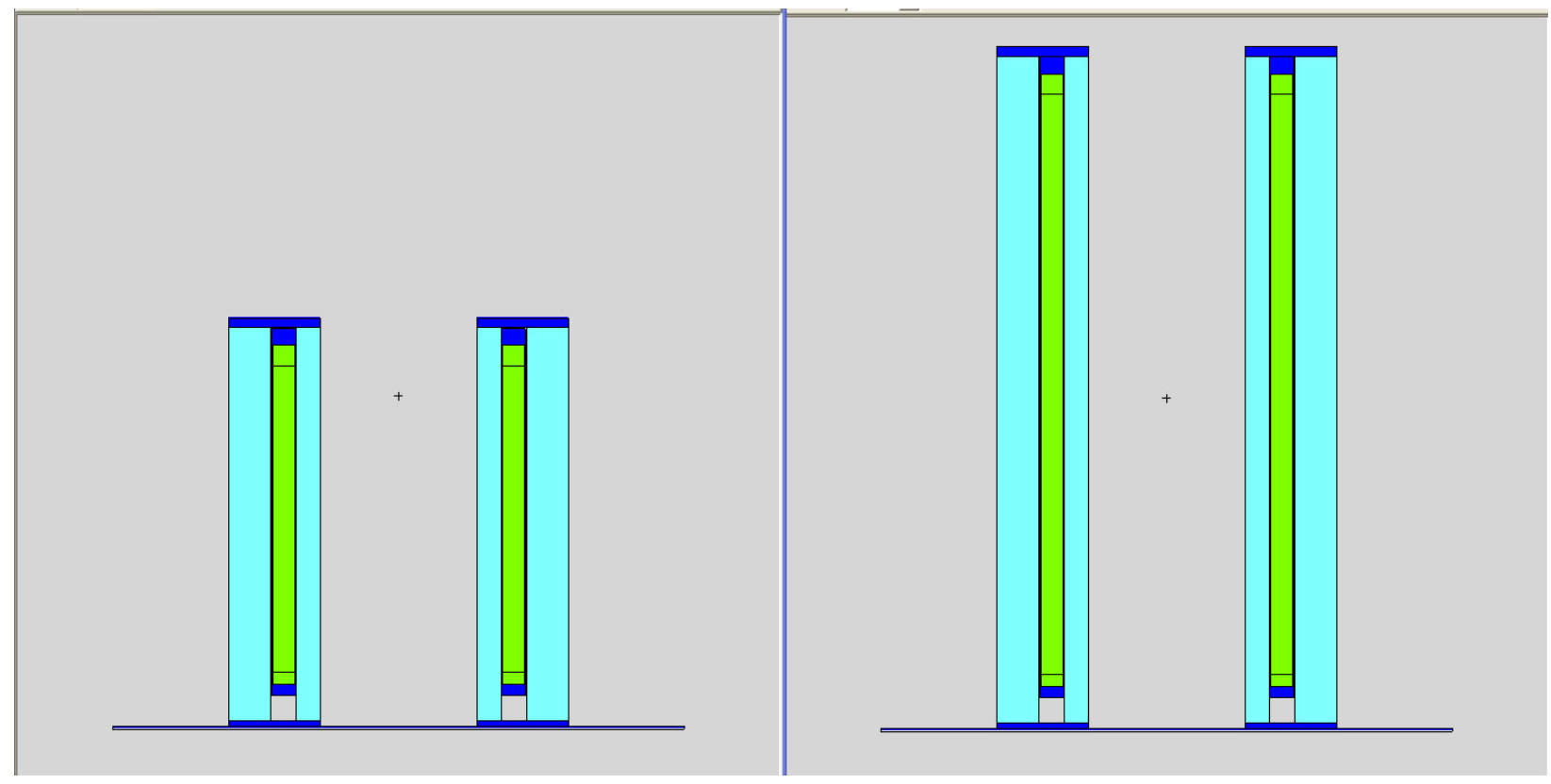

Figure 2.4. Comparison of the ABUNCL HDPE banks using 32.2-cm (12.7-inch) active length (left) and 61.0-cm (24-inch) active length ${ }^{10} B$-lined tubes (right).

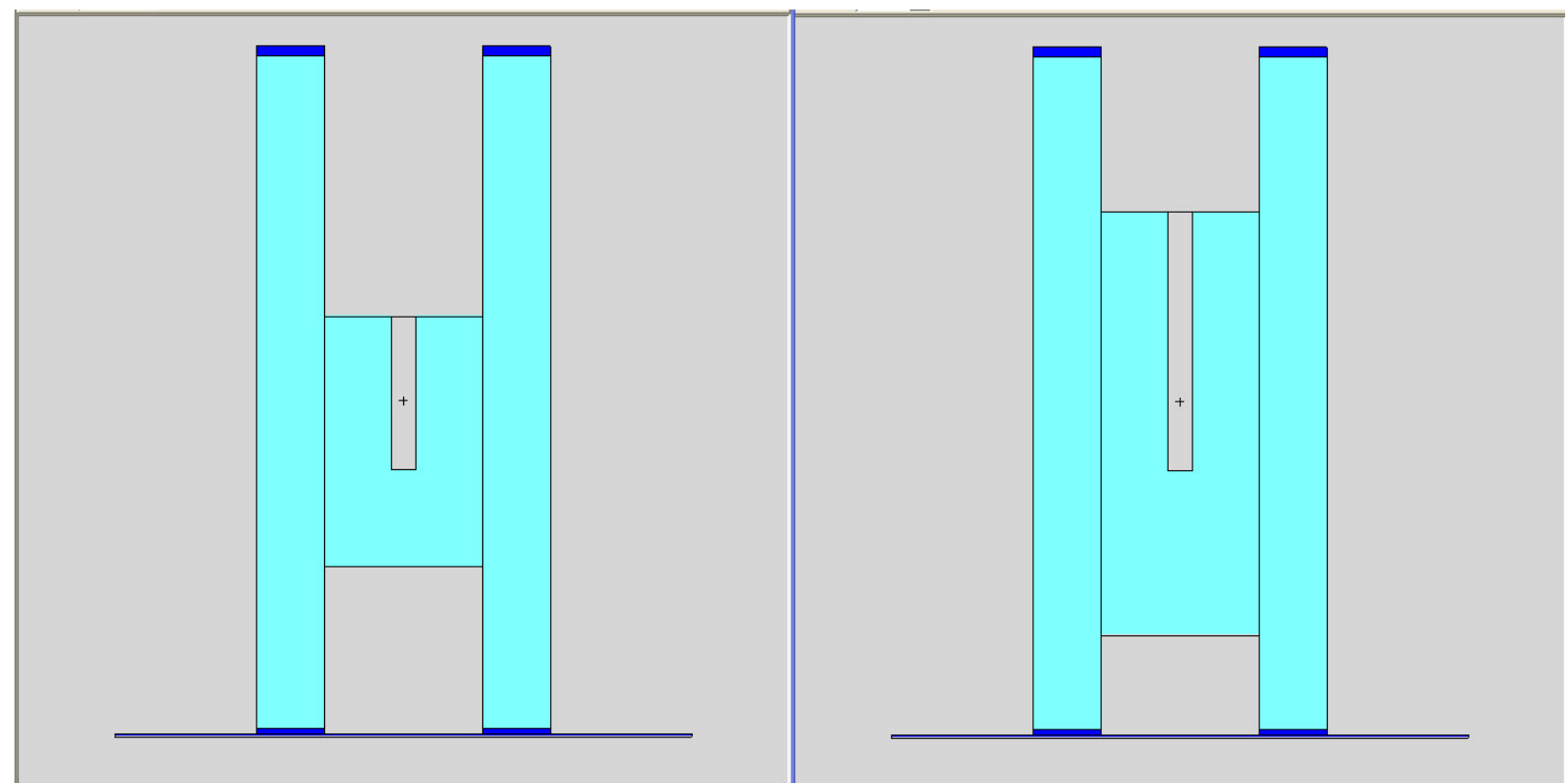

Figure 2.5. Comparison of the ABUNCL HDPE source blocks using source block with original (left) and scaled dimensions (right). 
Table 2.3. Results for ABUNCL models using $61 \mathrm{~cm}{ }^{10}$ B-lined tubes in place of $32 \mathrm{~cm}$ tubes.

\begin{tabular}{|c|c|c|c|c|c|c|}
\hline \multirow{2}{*}{ Detector } & \multirow{2}{*}{$\begin{array}{c}\text { Total \# Tubes, } \\
\text { Configuration, \& } \\
\text { Fuel Cavity } \\
\text { H x L x W (cm) }\end{array}$} & \multicolumn{5}{|c|}{$\frac{\text { Efficiency }(\varepsilon), \text { Die-Away Time }(\tau) \& \text { FOM }=\varepsilon^{2} / \tau}{\text { ABUNCL }}$} \\
\hline & & $\begin{array}{l}\text { No. Moles } \\
{ }_{10} \mathrm{~B}\end{array}$ & $\begin{array}{c}\varepsilon \\
\text { (No } \\
\text { LEC) }\end{array}$ & $\begin{array}{c}\varepsilon \\
(100 \\
\mathrm{keV})\end{array}$ & $\begin{array}{c}\text { Avg. } \\
\tau \\
(\mu \mathrm{s})\end{array}$ & $\begin{array}{c}\text { FOM } \\
(\text { No LEC) } \\
(\%)^{2} / \mu \mathrm{S}\end{array}$ \\
\hline $\begin{array}{c}\text { ABUNCL-II Active BWR } \\
\text { "12.7 in" } \\
\text { Original Source Block }\end{array}$ & $\begin{array}{c}16 \text { tubes } \\
3 \text { Rectangular banks } \\
41.3 \times 16.5 \times 16.5\end{array}$ & 0.07 & $5.1 \%$ & $4.7 \%$ & 184 & 0.14 \\
\hline $\begin{array}{c}\text { ABUNCL-II Active BWR } \\
\text { "24 in" } \\
\text { Original Source Block } \\
\end{array}$ & $\begin{array}{c}16 \text { tubes } \\
3 \text { Rectangular banks } \\
70.0 \times 16.5 \times 16.5 \\
\end{array}$ & 0.13 & $6.7 \%$ & $6.3 \%$ & 199 & 0.23 \\
\hline $\begin{array}{c}\text { ABUNCL-II Active BWR } \\
\text { "24 in" } \\
\text { Long Source Block }\end{array}$ & $\begin{array}{c}16 \text { tubes } \\
3 \text { Rectangular banks } \\
70.0 \times 16.5 \times 16.5 \\
\end{array}$ & 0.13 & $7.1 \%$ & $6.6 \%$ & 204 & 0.25 \\
\hline
\end{tabular}

\subsection{Multi-row ABUNCLs}

It is clear that multiple rows of ${ }^{10} \mathrm{~B}$-lined tubes are required to obtain a reasonable efficiency for the ABUNCL. The FOM for the extended HDPE active ABUNCL BWR assembly with 61.0-cm ${ }^{10} \mathrm{~B}$-lined tubes was still only $6 \%$ that of the ${ }^{3} \mathrm{He}$-based UNCL-II BWR active configuration $(0.25$ versus 4.2). To increase the FOM, the HDPE assembly was expanded to include multiple rows of ${ }^{10} \mathrm{~B}$-lined tubes. All models described in this section used the taller HDPE assembly with 61.0$\mathrm{cm}$ active length tubes.

Multi-row models were made with either staggered or aligned rows. The 3 and 5-row configurations are pictured in Figure 2.6 and Figure 2.7. These multi-row models eliminated the beveling in the left and right blocks, shortened the left and right blocks, and made new corner blocks. The tubes in the corner blocks were arranged at $45^{\circ}$ angles to the fuel cavity, and the between-row spacing were $0.32-\mathrm{cm}(0.125$-inch). The tubes in the front rows of the left and right blocks were moved closer to the cavity, from $2.54-\mathrm{cm}(1.0-\mathrm{inch})$ to $1.27-\mathrm{cm}(0.5$-inch). The direct-replacement models had six tubes per row, while the updated multi-row models have seven tubes per row in the left and right blocks. All of these modifications were made to maximize the number of ${ }^{10} \mathrm{~B}$-lined tubes and create a modular modeling geometry. 


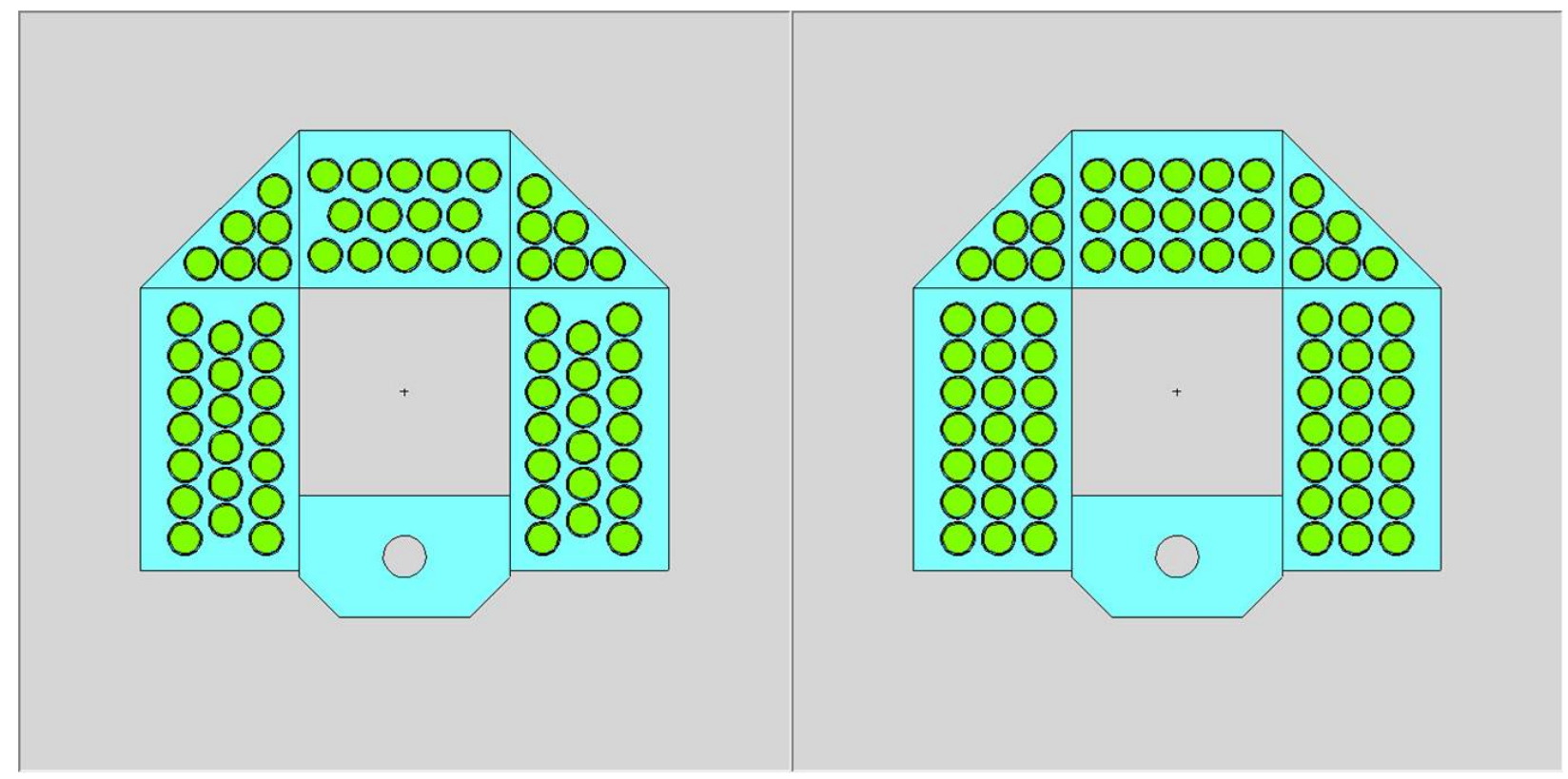

Figure 2.6. Comparison of 3-row ABUNCLs with staggered (left) and aligned rows (right).

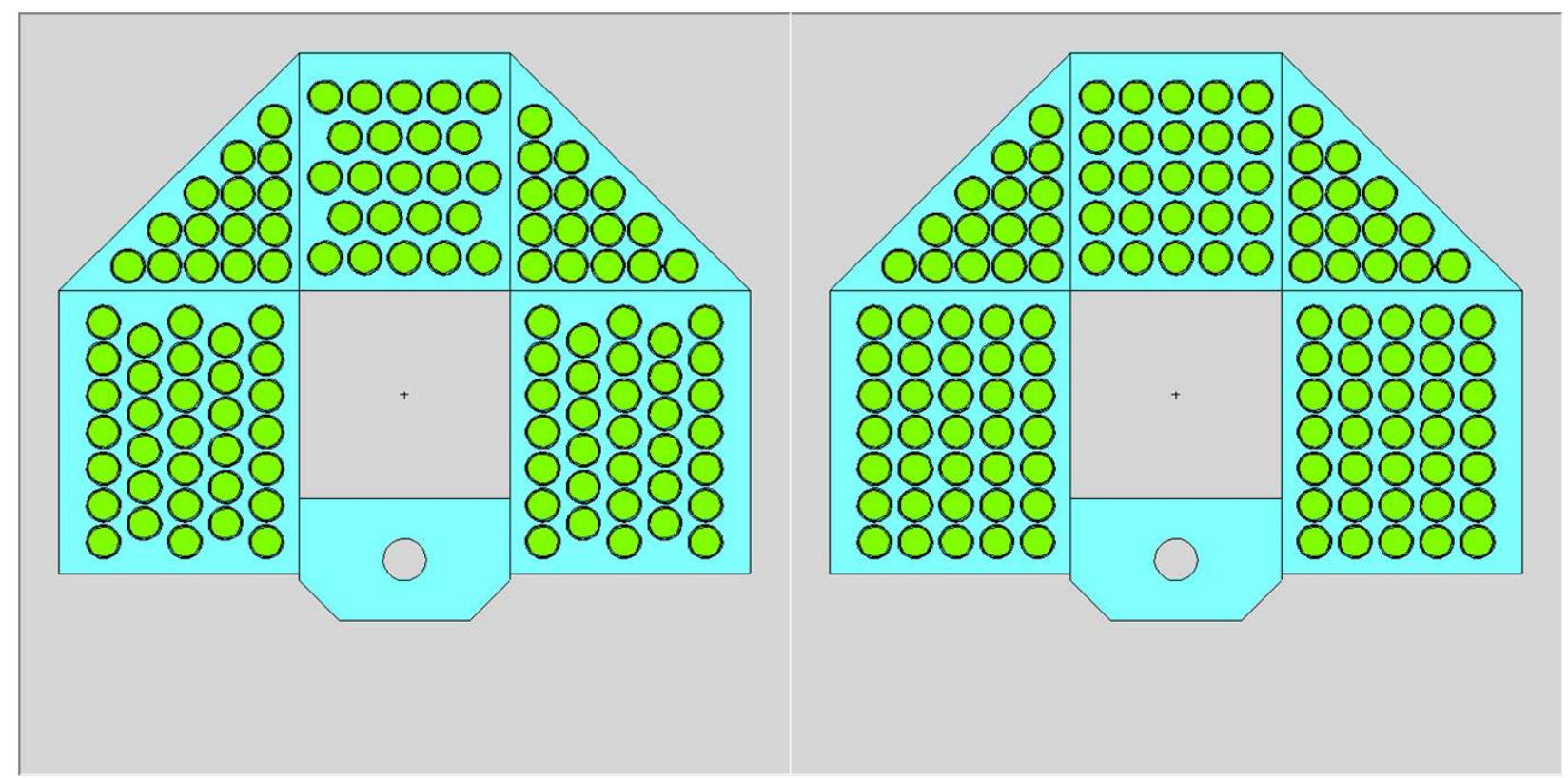

Figure 2.7. Comparison of 5-row ABUNCLs with staggered (left) and aligned rows (right).

The efficiencies and die-away times for the multi-row baseline models are listed in Table 2.4. The footprint and estimated total mass of each detector system are also given. For comparison, the estimated mass of the ${ }^{3} \mathrm{He}$-based active UNCL-II BWR system is $32.6 \mathrm{~kg}$. In general, increasing the number of rows significantly increased the efficiency of the system while only slightly increasing the die-away time. The slight difference in the number of tubes between the 
staggered and aligned-row models had no significant effect on either the efficiency or the dieaway time.

Table 2.4. Results for multi-row ABUNCL baseline models using staggered and aligned rows.

\begin{tabular}{|c|c|c|c|c|c|c|}
\hline \multirow[b]{2}{*}{$\begin{array}{l}\text { ABUNCL-II Active } \\
\text { BWR Configuration }\end{array}$} & \multirow{2}{*}{$\begin{array}{c}\text { Total \# Tubes, } \\
\text { Assembly } \\
\text { H x L x W (cm), } \\
\text { Total Mass (kg) }\end{array}$} & \multicolumn{5}{|c|}{ Efficiency $(\varepsilon)$, Die-Away Time $(\tau) \&$ FOM $=\varepsilon^{2} / \tau$} \\
\hline & & No. Moles ${ }^{10} \mathrm{~B}$ & $\begin{array}{c}\varepsilon \\
\text { (No LEC) }\end{array}$ & $\begin{array}{c}\varepsilon \\
(100 \mathrm{keV})\end{array}$ & $\tau(\boldsymbol{\mu s})$ & $\begin{array}{c}\text { FOM } \\
(\text { No LEC) } \\
(\%)^{2} / \mu \mathrm{s}\end{array}$ \\
\hline 2 Staggered Rows & $\begin{array}{c}35 \text { tubes } \\
70.0 \times 35.3 \times 34.9 \\
47.7 \mathrm{~kg} \\
\end{array}$ & 0.29 & $9.9 \%$ & $9.2 \%$ & 119 & 0.8 \\
\hline 3 Staggered Rows & $\begin{array}{c}54 \text { tubes } \\
70.0 \times 38.4 \times 41.3 \\
62.2 \mathrm{~kg} \\
\end{array}$ & 0.45 & $13.9 \%$ & $12.9 \%$ & 122 & 1.6 \\
\hline 4 Staggered Rows & $\begin{array}{c}70 \text { tubes } \\
70.0 \times 41.6 \times 47.6 \\
78.5 \mathrm{~kg}\end{array}$ & 0.59 & $17.1 \%$ & $15.9 \%$ & 127 & 2.3 \\
\hline 5 Staggered Rows & $\begin{array}{c}89 \text { tubes } \\
70.0 \times 44.8 \times 54.0 \\
95.7 \mathrm{~kg}\end{array}$ & 0.75 & $19.6 \%$ & $18.2 \%$ & 129 & 3.0 \\
\hline 2 Aligned Rows & $\begin{array}{c}38 \text { tubes } \\
70.0 \times 35.3 \times 34.9 \\
47.2 \mathrm{~kg}\end{array}$ & 0.32 & $9.9 \%$ & $9.2 \%$ & 115 & 0.9 \\
\hline 3 Aligned Rows & $\begin{array}{c}57 \text { tubes } \\
70.0 \times 38.4 \times 41.3 \\
61.7 \mathrm{~kg}\end{array}$ & 0.48 & $13.9 \%$ & $12.9 \%$ & 119 & 1.6 \\
\hline 4 Aligned Rows & $\begin{array}{c}76 \text { tubes } \\
70.0 \times 41.6 \times 47.6 \\
77.5 \mathrm{~kg}\end{array}$ & 0.64 & $17.1 \%$ & $15.9 \%$ & 122 & 2.4 \\
\hline 5 Aligned Rows & $\begin{array}{c}95 \text { tubes } \\
70.0 \times 44.8 \times 54.0 \\
94.7 \mathrm{~kg}\end{array}$ & 0.80 & $19.7 \%$ & $18.3 \%$ & 124 & 3.1 \\
\hline
\end{tabular}

The FOM contour plot for the multi-row baseline models is shown in Figure 2.8. The FOM increases with the number of tubes to 3.1 for the 95-tube, 5-aligned-row model, but still falls short of the target FOM value of 4.2 for the ${ }^{3} \mathrm{He}$-based active UNCL-II BWR system. The aligned- row configuration has a slightly higher FOM than the staggered-row design because of its marginally better efficiency and die-away time values. 


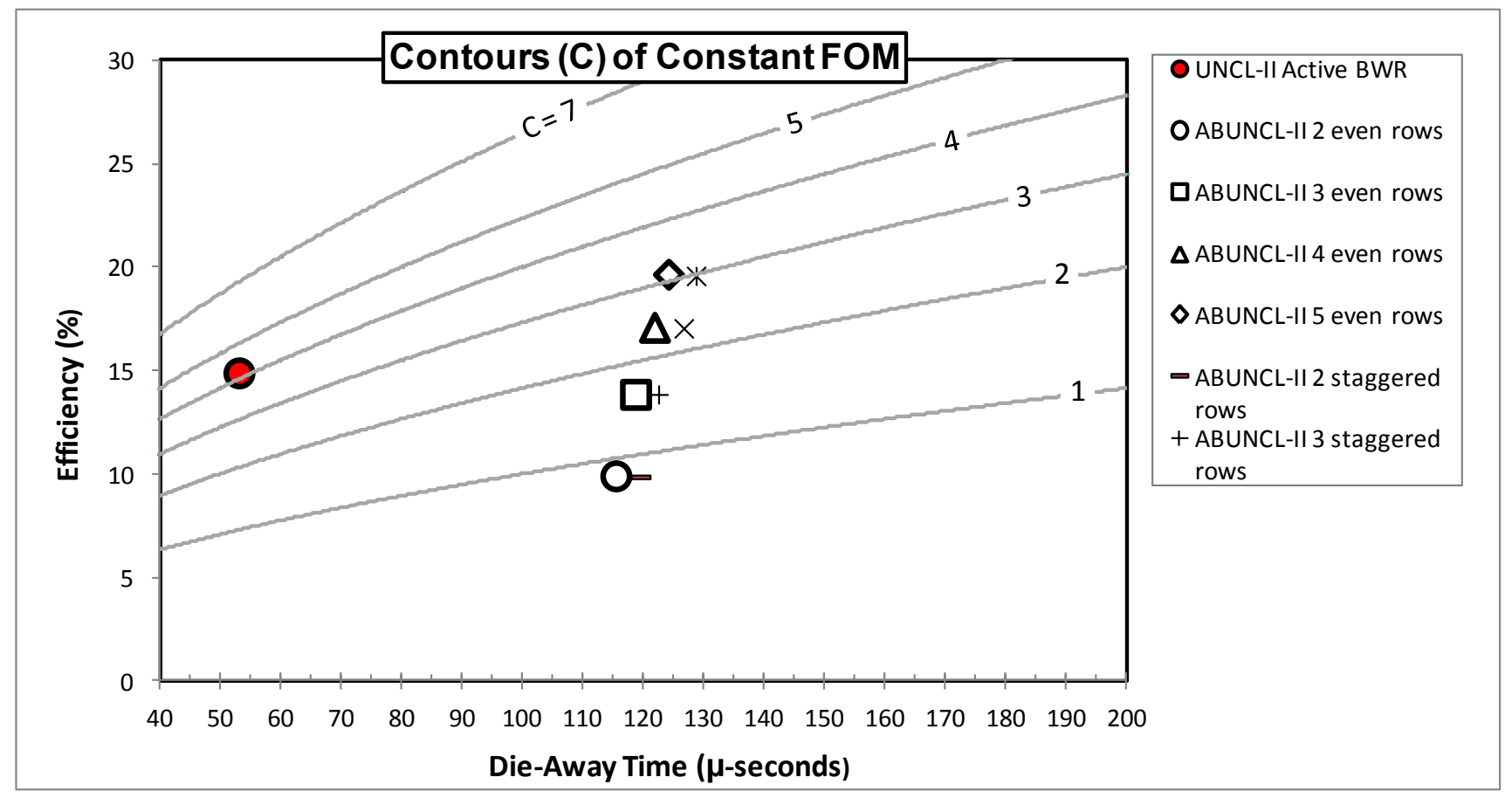

Figure 2.8. FOM values for multi-row ABUNCL models.

\subsection{Multi-row ABUNCLs with Cd}

The aligned-row models were then tested with a $0.04-\mathrm{cm}$ thick $\mathrm{Cd}$ layer with a $0.1-\mathrm{cm}$ fiberglass (type R) backing lining the inner cavity in an attempt to decrease the die-away time. This lining is similar to that used by Menlove et al. for calibration of the UNCL-I [Menlove 1997]. The fiberglass type was selected because its composition does not include boron, and will thus provide less neutron absorption. The models were also tested with the same $\mathrm{Cd} /$ fiberglass liner on the exterior of the HDPE assembly to reflect neutrons back into the detector system.

The results from the Cd-lined models are shown in Figure 2.9 and Figure 2.10. The inner Cd layer increases the moderation effect on the neutrons entering the HDPE assembly and reduces the die-away time. This decrease in die-away time, however, is offset by a decrease in efficiency, resulting in lower FOM values. Placing a $\mathrm{Cd}$ liner on the outside of the assembly has no significant effect on the FOM. 


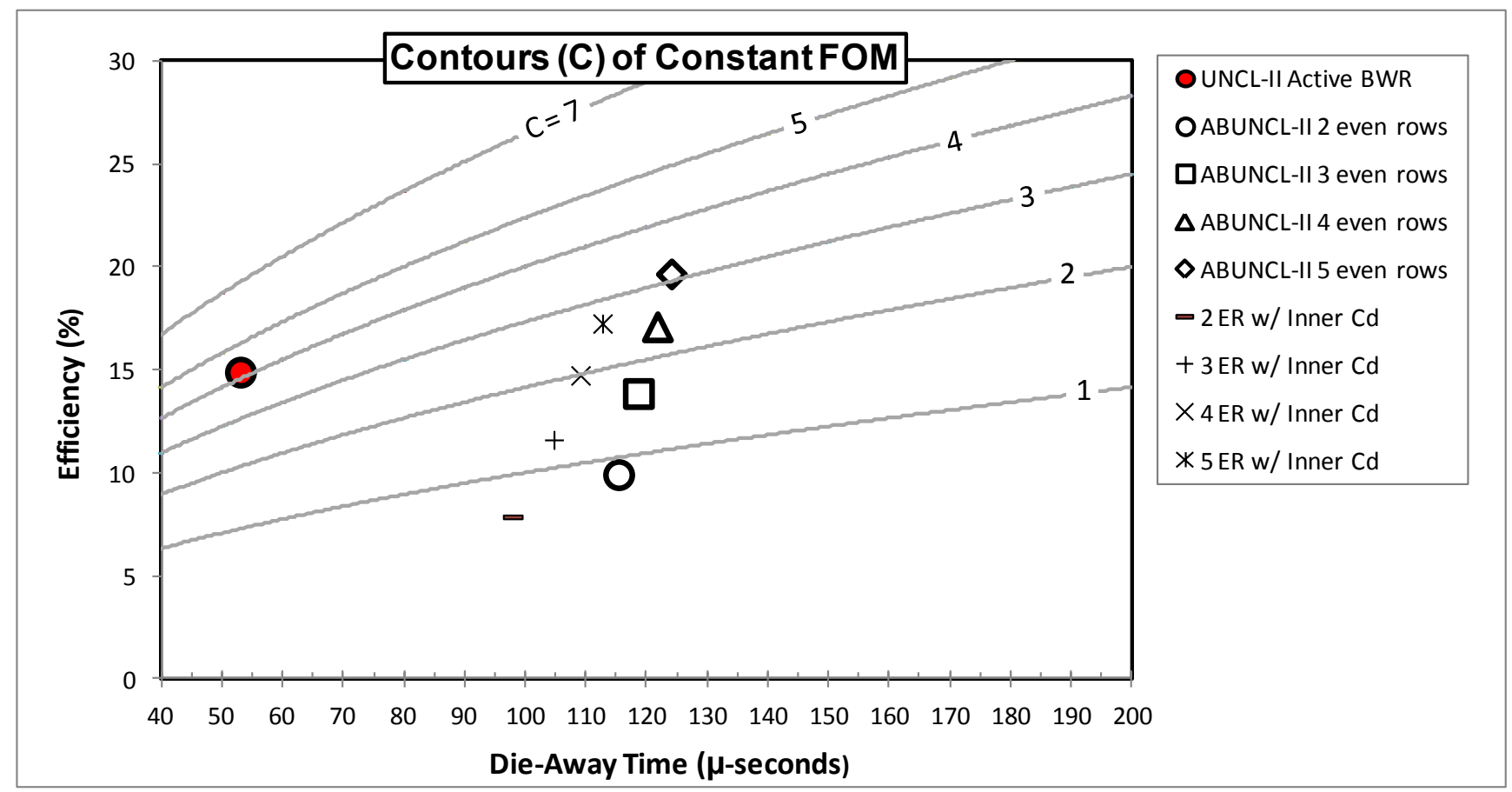

Figure 2.9. FOM values for aligned-row models with 0.4-mm $\mathrm{Cd}$ liner on inside of fuel cavity.

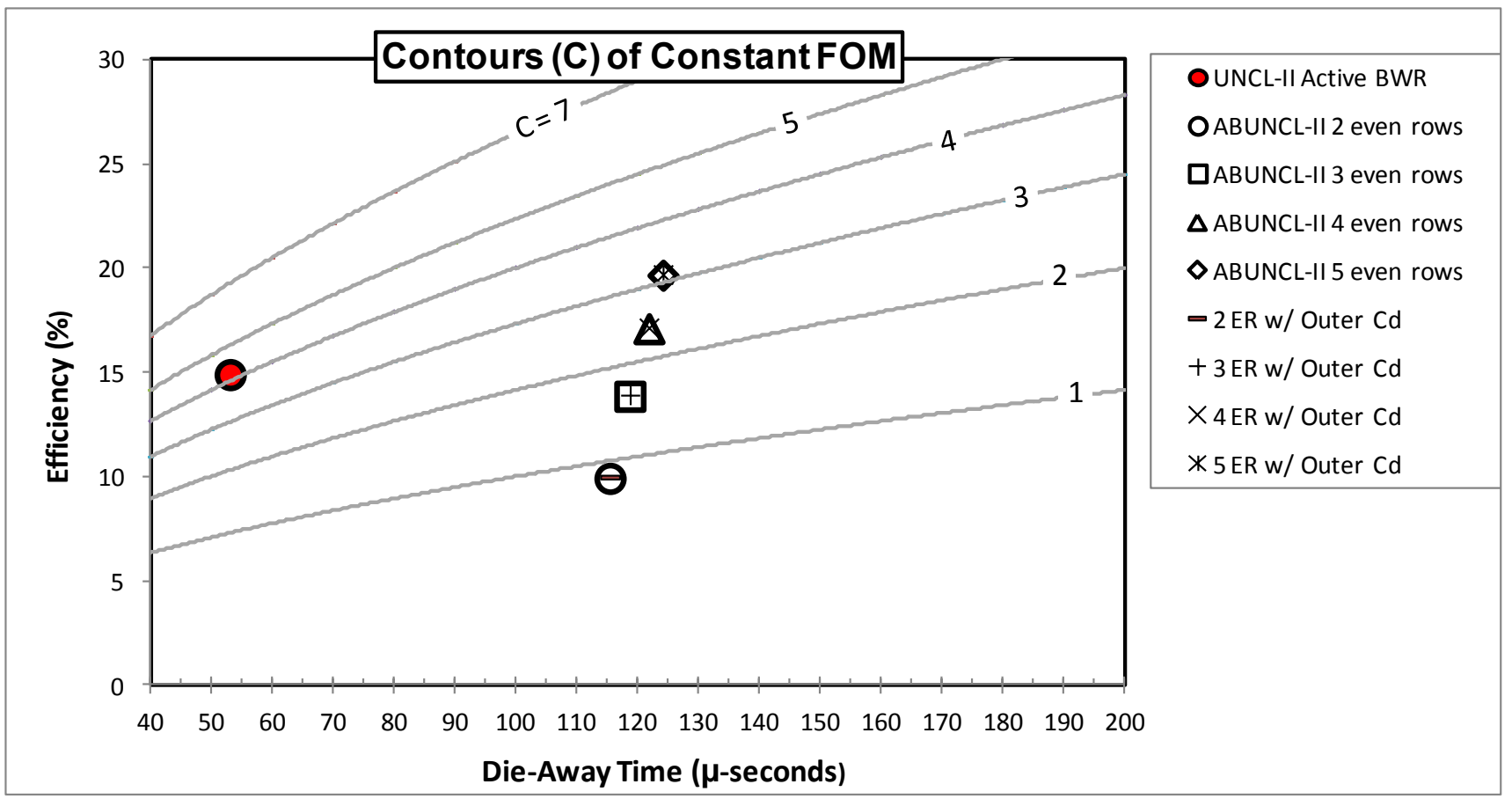

Figure 2.10. FOM values for aligned-row models with 0.4-mm Cd liner on outside of HDPE assembly. 


\subsection{HDPE Assembly Modifications with Multi-row ABUNCLs}

Several parameters in the HDPE assembly with 5 rows of staggered tubes were varied to determine their effect on the model FOM. The leading edge, or distance from the inner edge of the HDPE to the plane of the first row of tubes, was tested for $0.5 \mathrm{~cm}, 0.75 \mathrm{~cm}$, and $1.0 \mathrm{~cm}$ to move the detectors closer to the fuel cavity. As shown in Figure 2.11, reducing the leading edge resulted in slight improvements to the model die-away time and FOM.

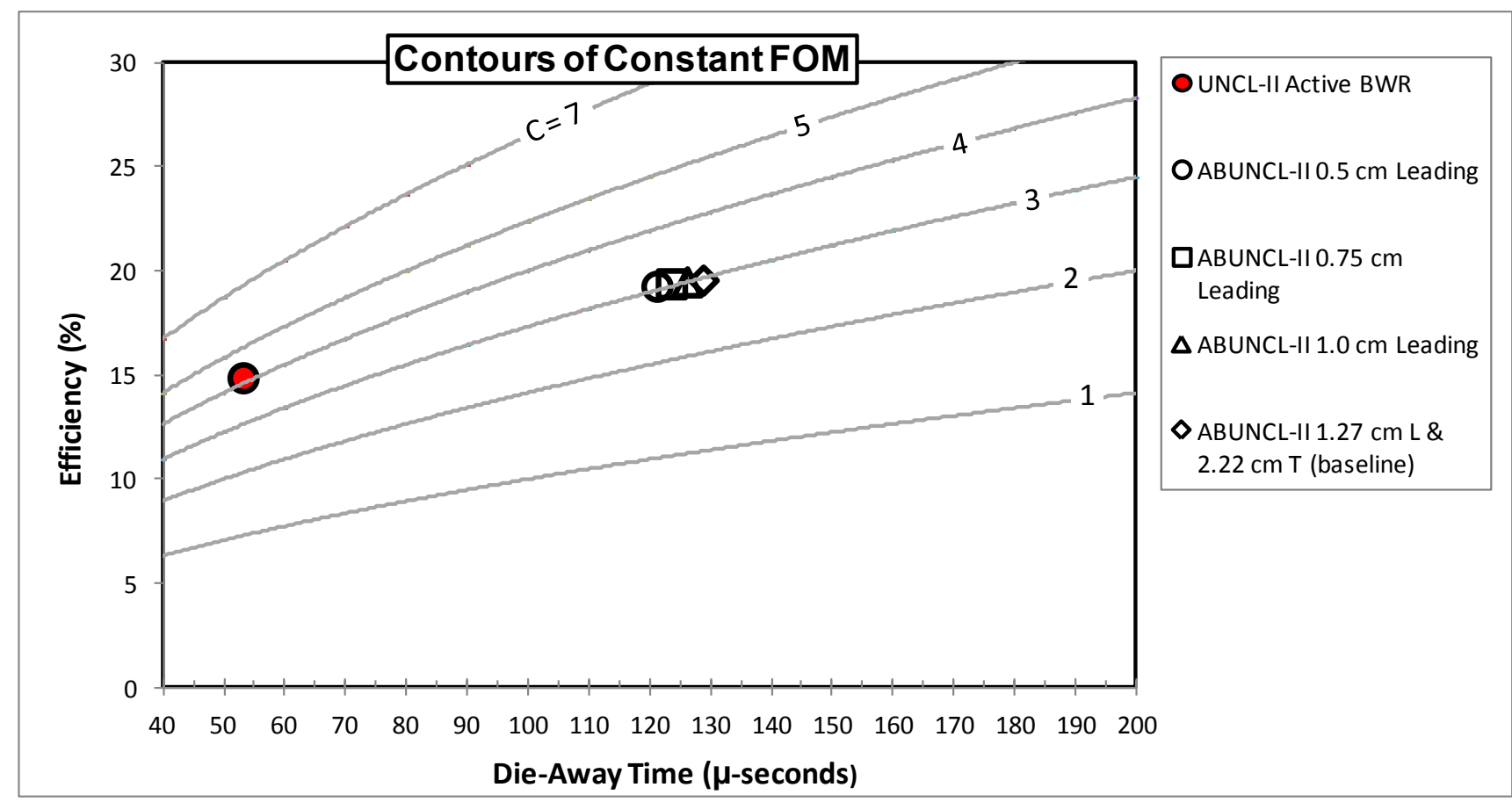

Figure 2.11. FOM values for variations in the HDPE leading edge with trailing edge at constant $2.22 \mathrm{~cm}$.

Reducing the trailing edge from the baseline $2.22 \mathrm{~cm}$ to $1.0 \mathrm{~cm}, 1.5 \mathrm{~cm}$, and $2.0 \mathrm{~cm}$ resulted in similar improvements to the die-away time. However, the losses in efficiency due to the reduced amount of reflective moderating material resulted in a modest net decrease in the model FOM (see Figure 2.12). 


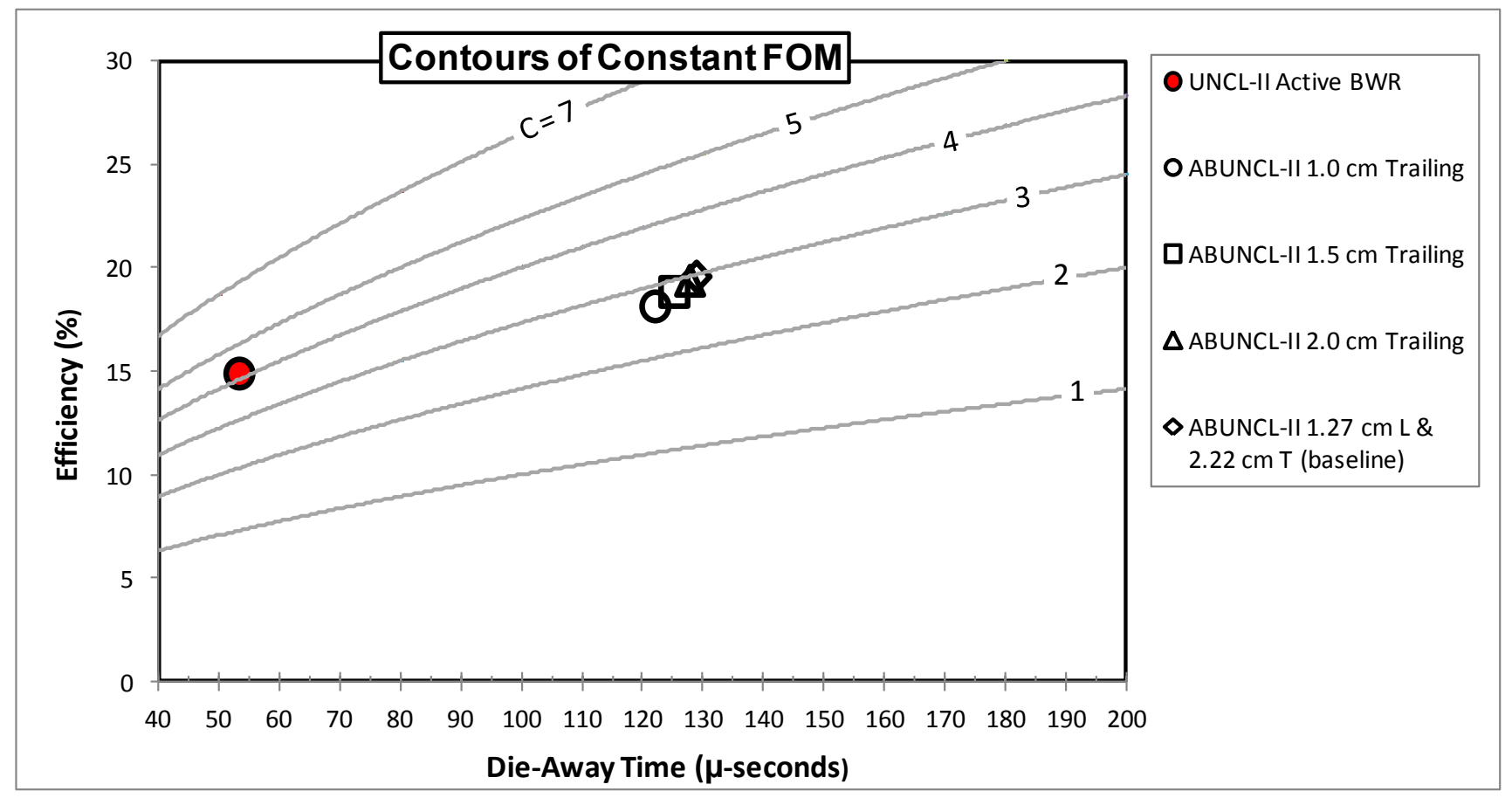

Figure 2.12. FOM values for variations in the HDPE trailing edge with leading edge at constant $1.27 \mathrm{~cm}$.

The interstitial polyethylene distances were also tested by reducing the distances between the tubes in the 5-staggered-row tube arrangement ( 89 total tubes) such that the tubes were only 0.22 $\mathrm{cm}$ apart at closest approach. The leading and trailing edges were kept at their baseline values of $1.27 \mathrm{~cm}$ and $2.22 \mathrm{~cm}$, respectively. One advantage of the close-packed arrangement is its considerably smaller mass: $73.0 \mathrm{~kg}$ compared to $95.7 \mathrm{~kg}$ for the baseline 89 -tube ABUNCL. However, this configuration shows a notable decrease in efficiency and FOM from the baseline arrangement (see Figure 2.14). The FOM is comparable to the four-staggered-row, 70-tube ABUNCL. 


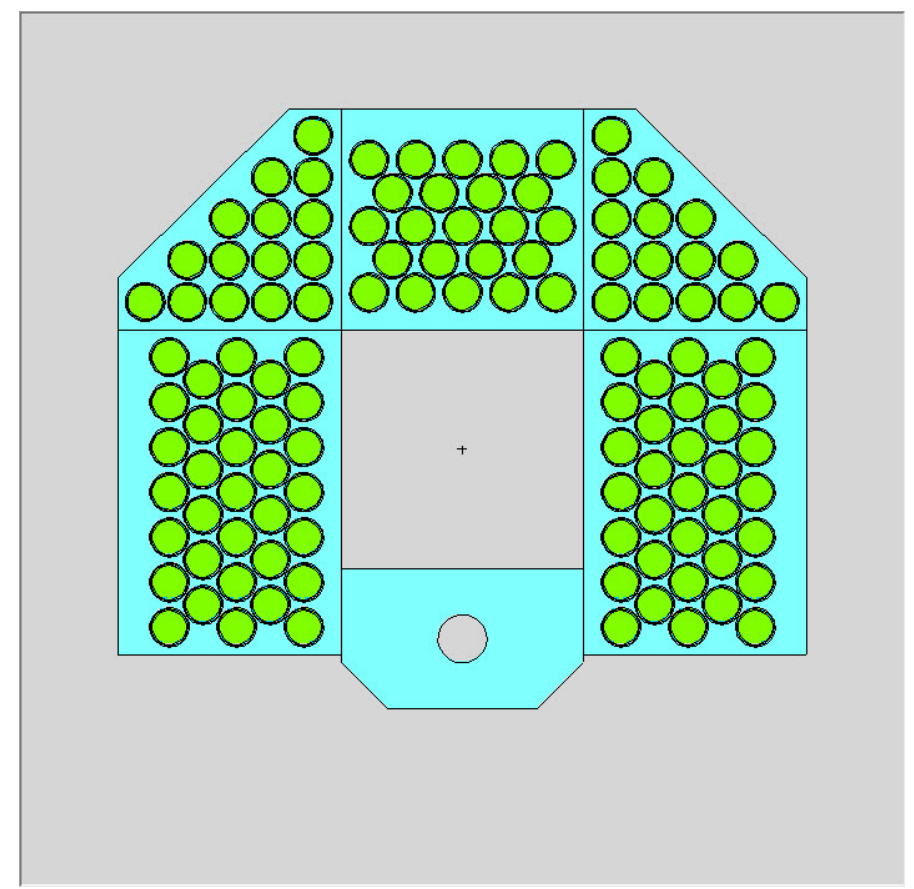

Figure 2.13. Top view of 5-row close-packed model.

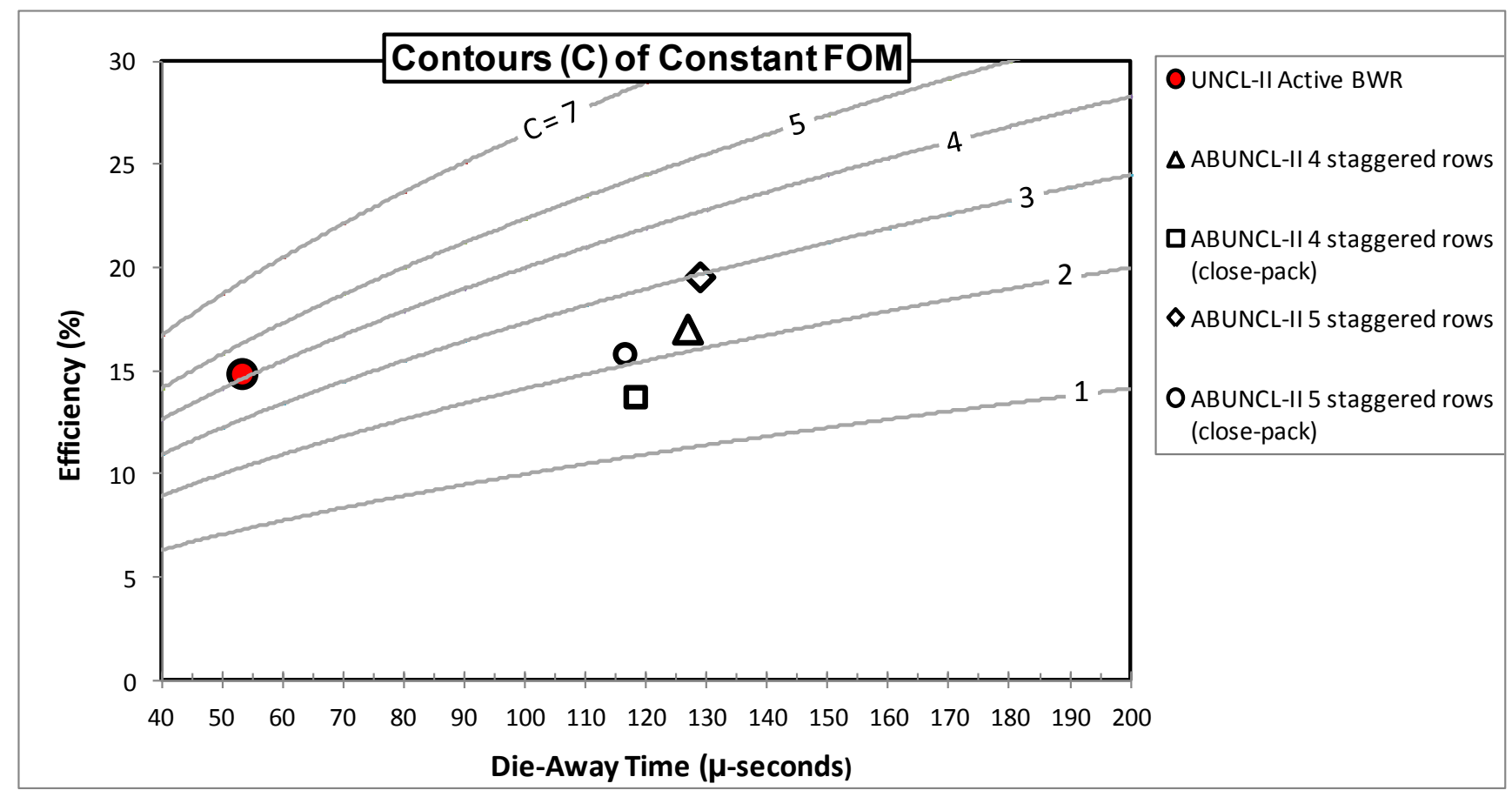

Figure 2.14. FOM values showing effects for 4-row and 5-row close-packing. 


\subsection{Multi-row ABUNCLs with Alternative Moderating Materials}

The HPDE moderator surrounding the tubes was replaced with polyvinyl toluene (PVT) to test the effect of a "faster" moderator, as pictured in Figure 2.15. Polyvinyl toluene has lower hydrogen content than HDPE, so neutrons travel farther between scattering events, fewer neutrons are captured in the moderator, the epithermal neutron flux is increased, and more neutrons escape the system. The net effect on system performance is to significantly reduce the die-away time at the cost of efficiency. The FOM is reduced from $3.1 \mu$ s to $1.9 \mu \mathrm{s}$ in the 5-row, 95-tube arrangement, and from $0.9 \mu$ s to $0.4 \mu$ s in the 2-row, 38-tube ABUNCL (see Figure 2.16).

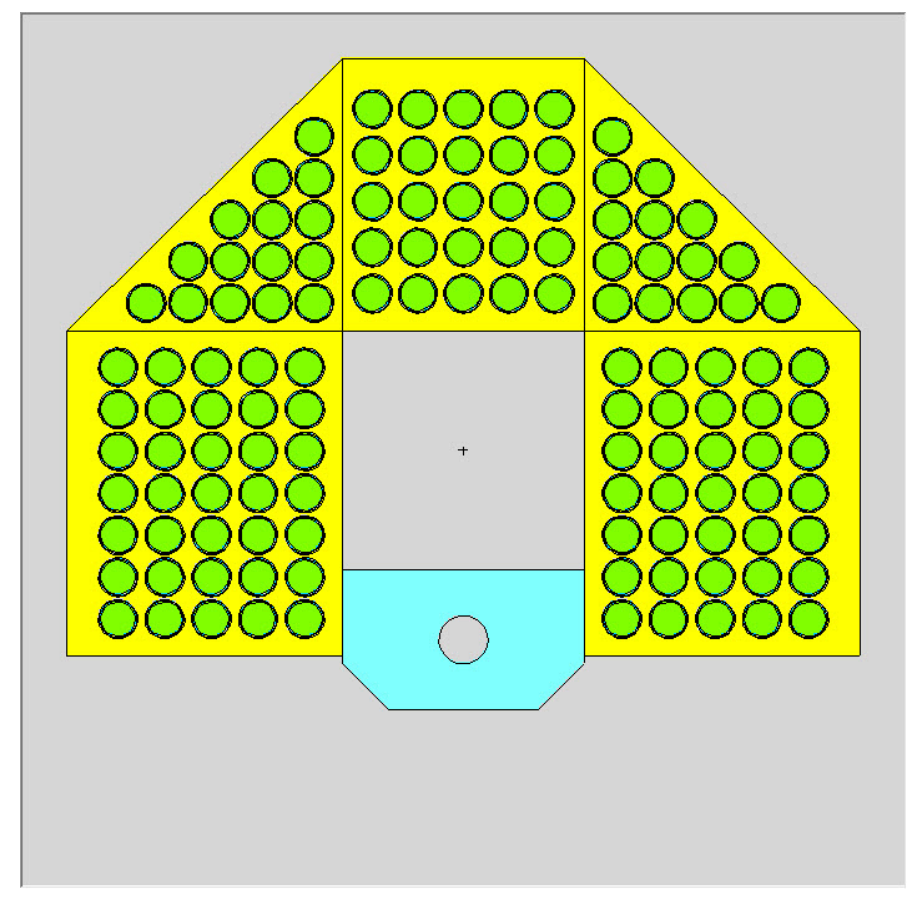

Figure 2.15. Top view of ABUNCL with tube moderator replaced with polyvinyl toluene. 


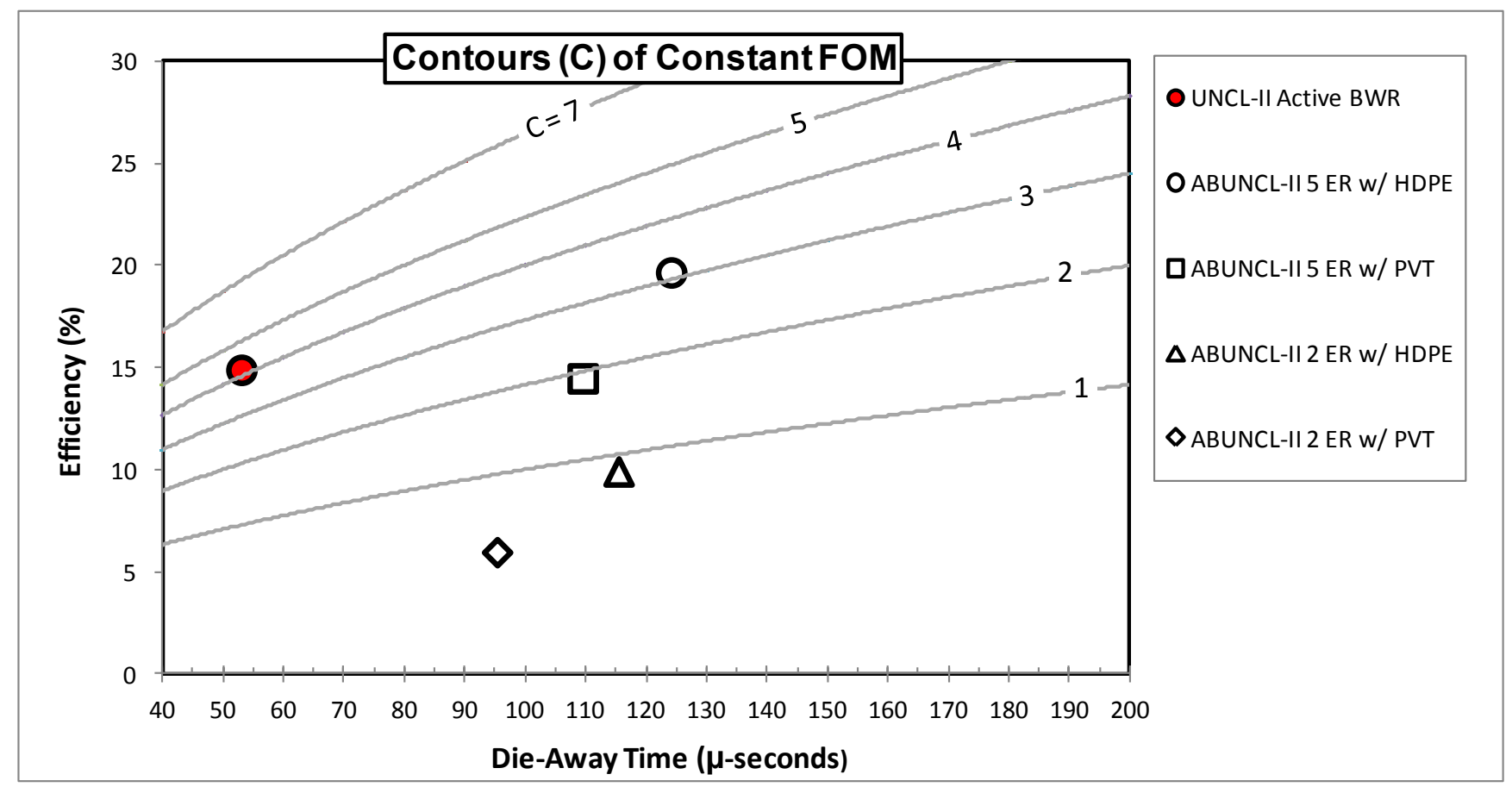

Figure 2.16. FOM values showing effect of replacing HDPE by PVT as moderator in selected ABUNCL configurations.

\subsection{Effect of Boron Lining Thickness on Multi-row ABUNCLs}

Several MCNPX runs were made with various boron metal lining thicknesses in the five alignedrow model to determine the effect of the ${ }^{10} \mathrm{~B}$ lining on the FOM. The results are shown in Figure 2.17 and Table 2.5 for lining thicknesses between $0.75 \mu \mathrm{m}$ and $2.5 \mu \mathrm{m}$ of ${ }^{10} \mathrm{~B}$ metal. The FOM is very sensitive to the thickness of the ${ }^{10} \mathrm{~B}$ lining, as the efficiency increases to a certain point then decreases as more reaction products are absorbed in the lining without reaching the proportional gas. The die-away time decreases with increasing lining thickness as more neutrons are captured in the lining.

The neutron capture, total count efficiency, and die-away time characteristics of the 95-tube model are shown in Figure 2.18. Compared to a single tube, the neutron capture and total count efficiencies of a ${ }^{10} \mathrm{~B}$-lined tube assembly are much greater, and the total count efficiency "peak" occurs with a much thinner ${ }^{10} \mathrm{~B}$ lining $(\sim 1 \mu \mathrm{m}$ compared to $\sim 2 \mu \mathrm{m}$ for a single tube [Rogers 2012]). 


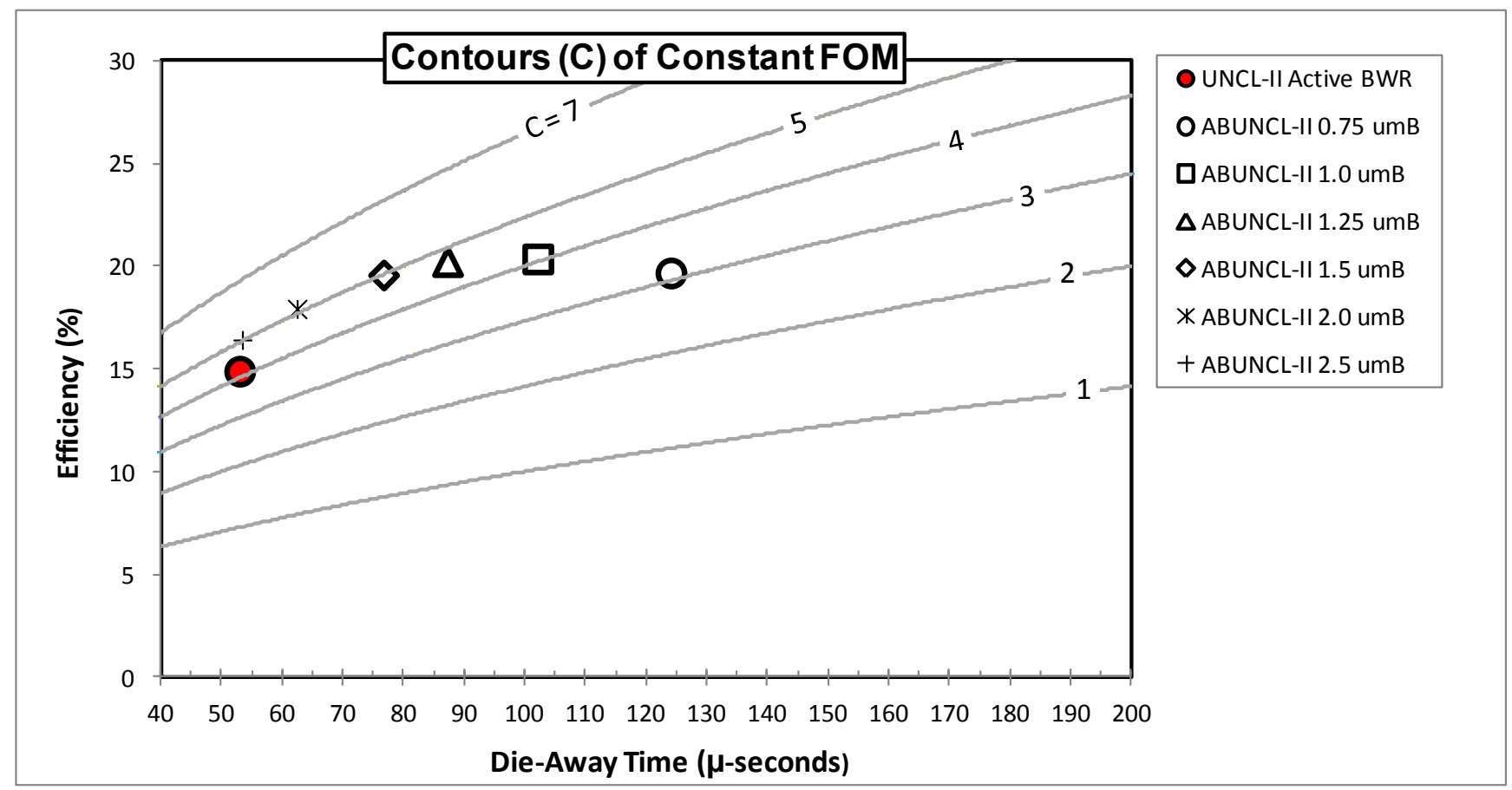

Figure 2.17. FOM values for various ${ }^{10} \mathrm{~B}$ metal lining thicknesses in 5-aligned-row, 95-tube ABUNCL model.

Table 2.5. Effect of ${ }^{10} \mathrm{~B}$ lining thickness on efficiency, die-away time, FOM in 5-aligned-row, 95-tube model

\begin{tabular}{|c|c|c|c|c|}
\hline $\begin{array}{c}{ }^{10} \mathrm{~B} \\
\text { Metal } \\
\text { Lining }\end{array}$ & $\begin{array}{c}\varepsilon \\
\text { (no LEC) }\end{array}$ & $\begin{array}{c}\varepsilon \\
(100 \mathrm{keV})\end{array}$ & $\begin{array}{c}\text { Avg. } \tau \\
(\mu s)\end{array}$ & $\begin{array}{c}\text { FOM } \\
(\text { No LEC) } \\
(\%)^{2} / \mu \mathrm{s}\end{array}$ \\
\hline $0.75 \mu \mathrm{m} \mathrm{B}$ & $19.7 \%$ & $18.3 \%$ & 124 & 3.1 \\
\hline $1.0 \mu \mathrm{m} \mathrm{B}$ & $20.4 \%$ & $18.6 \%$ & 102 & 4.1 \\
\hline $1.25 \mu \mathrm{m} \mathrm{B}$ & $20.2 \%$ & $18.1 \%$ & 87 & 4.7 \\
\hline $1.5 \mu \mathrm{m} \mathrm{B}$ & $19.6 \%$ & $17.3 \%$ & 77 & 5.0 \\
\hline $2.0 \mu \mathrm{m} \mathrm{B}$ & $17.9 \%$ & $15.9 \%$ & 62 & 5.1 \\
\hline $2.5 \mu \mathrm{m} \mathrm{B}$ & $16.4 \%$ & $14.5 \%$ & 53 & 5.0 \\
\hline
\end{tabular}




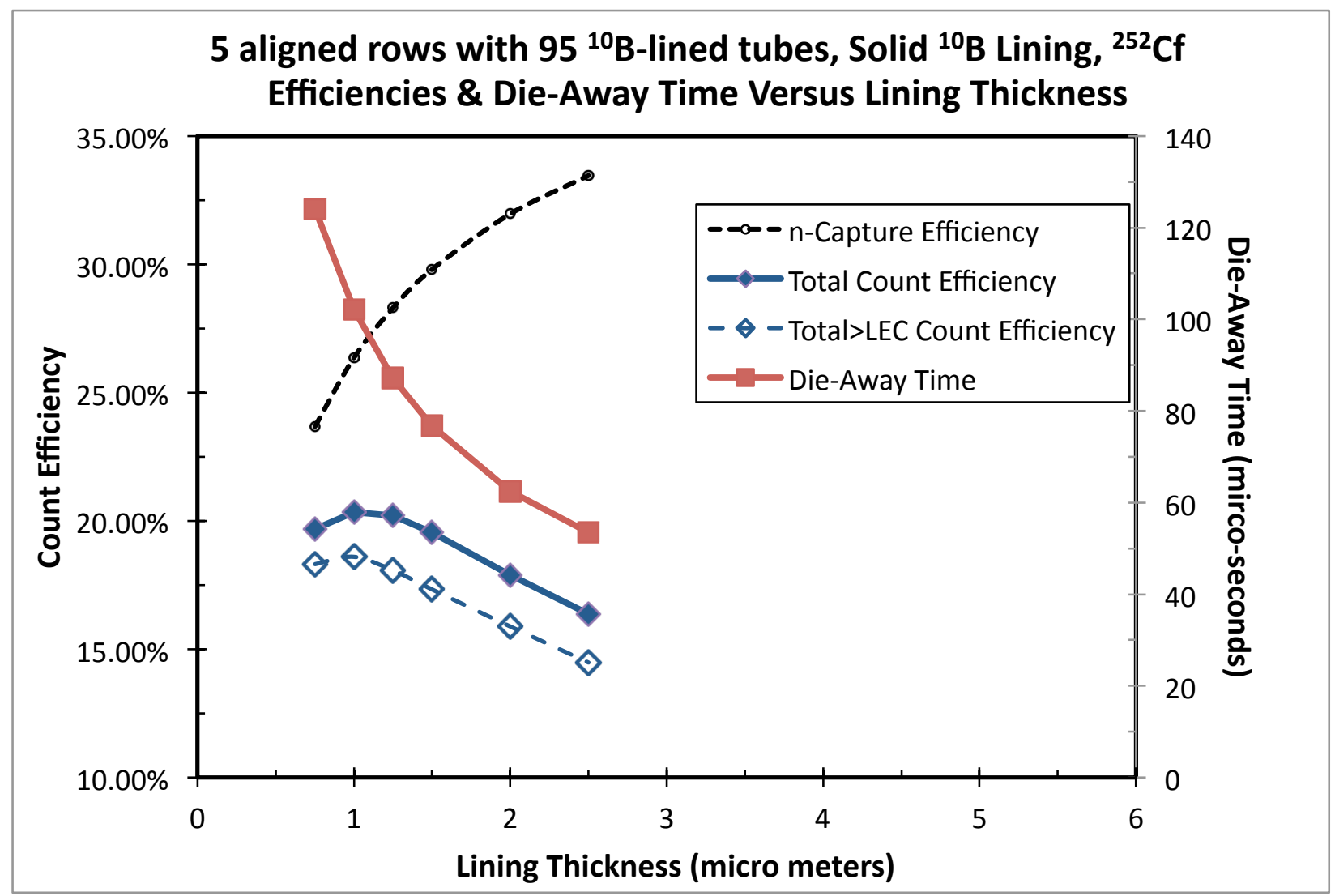

Figure 2.18. Effect of ${ }^{10} \mathrm{~B}$ lining thickness on n-capture reactions, count efficiency, and die-away time in individual ${ }^{10} \mathrm{~B}$-lined detector system.

The ${ }^{10} \mathrm{~B}$-lined tubes used for the prototype coincidence counter in Task 3 of this project are planned to be preexisting GE Reuter-Stokes models with 2.54-cm (1-inch) diameters and a lining thickness and composition kept proprietary to GE Reuter-Stokes. The $0.75 \mu \mathrm{m}$ boron metal lining was used as the model basis for this work because it most closely agreed with the total count rate performance of individually measured ${ }^{10} \mathrm{~B}$-lined proportional counters in validation studies [Rogers 2012; Lintereur 2012]). This does not mean that the $0.75 \mu \mathrm{m}{ }^{10} \mathrm{~B}$ metal lining is used by GE Reuter-Stokes in their proportional counters, or that using it as the modeling basis accurately simulates the die-away time characteristics of a ${ }^{10} \mathrm{~B}$-based system. Since the die-away time is heavily dependent on the system geometry, it was not measured as part of the experimental validation process. Future work will focus on validating the efficiencies and dieaway times of a single bank of ${ }^{10} \mathrm{~B}$-lined tubes before constructing a full-scale prototype.

The die-away time, and thus the performance of a ${ }^{10} \mathrm{~B}$-lined coincidence counting system, will rely heavily on the thickness and composition of the ${ }^{10} \mathrm{~B}$ lining. Future work may update the model ${ }^{10} \mathrm{~B}$ lining thickness and composition based on die-away time characteristics and pulseheight shapes. For implementation of an ABUNCL, the optimization of the ${ }^{10} \mathrm{~B}$-lining thickness for best FOM may be possible by working with the vendor. 


\section{Conclusions}

This report discussed the development of MCNPX models of full-scale boron-based UNCL coincidence counters for applications in safeguards for Task 2 of the project Coincidence Counting With Boron-Based Alternative Neutron Detection Technology.

Boron-10-lined tubes with a $0.75-\mu \mathrm{m}{ }^{10} \mathrm{~B}$-metal lining were used as the basis for the direct replacement of the ${ }^{3} \mathrm{He}$ tubes in models of UNCL coincidence counters. These ABUNCL models had calculated efficiency values $32-34 \%$ that of the corresponding ${ }^{3} \mathrm{He}$-based UNCL models. The die-away times were calculated to be a factor of 3-3.5 greater in the ABUNCL models than the ${ }^{3} \mathrm{He}$-based UNCL models. These decreases in performance led to FOMs only 3.0-3.5\% that of the corresponding ${ }^{3} \mathrm{He}$-based ABUNCL models.

Adjusting the active ABUNCL-II BWR model to use a 24 -inch active length ${ }^{10} \mathrm{~B}$-lined tube and longer source block increased the efficiency from $5.1 \%$ to $7.1 \%$, but also increased the die-away time by $20 \mu \mathrm{s}$. This resulted in a net increase of $44 \%$ to the FOM over the corresponding 12.7inch ABUNCL model, from 0.14 to 0.25 .

Expanding the HDPE assembly to use multiple rows of ${ }^{10} \mathrm{~B}$-lined tubes significantly increased the efficiency and reduced the die-away time. The FOM for the 5-row, 95-tube (aligned-row) ABUNCL model was calculated to be 3.1 , still $26 \%$ less than the ${ }^{3} \mathrm{He}$-based UNCL. Lining the interior of the fuel cavity with $0.4-\mathrm{mm}$ of cadmium reduced the die-away time from $124 \mu \mathrm{s}$ to $113 \mu \mathrm{s}$, but the decrease in efficiency resulted in a net decrease in FOM, from 3.1 to 2.6. Changing the HDPE moderator materials to PVT had a similar effect, improving the die-away time but also decreasing the FOM of the system from 3.1 to 2.4.

Using the 5-row, 89-tube (staggered-row) ABUNCL model, and moving the rows of ${ }^{10} \mathrm{~B}$-lined tubes closer to the inner edge of the fuel cavity (from $1.27 \mathrm{~cm}$ to $0.5 \mathrm{~cm}$ ) reduced the die-away time and resulted in a marginal increase in FOM, from 3.0 to 3.1. Reducing the interstitial polyethylene distances ("close-packing") and reducing the trailing HDPE edge both negatively impacted the FOM.

The thickness and composition of the ${ }^{10} \mathrm{~B}$ lining appears to be the most sensitive parameter for ABUNCL models explored in this work. The FOM increased from 3.1 for the models using 0.75 $\mu \mathrm{m}{ }^{10} \mathrm{~B}$ metal to a maximum of 5.1 for the $2.0 \mu \mathrm{m}{ }^{10} \mathrm{~B}$ metal lining. Most of this increase was due to the drastic decrease in die-away time caused by the increased neutron capture efficiency in the ${ }^{10} \mathrm{~B}$ lining. The lining thickness and composition in the ${ }^{10} \mathrm{~B}$-lined tubes is proprietary to GE Reuter-Stokes; no information from the vendor on the actual ${ }^{10} \mathrm{~B}$ lining was used in this study. Analysis of model pulse height spectra for individual tubes indicates that the lining in the GE Reuter-Stokes tubes could be thicker and made of different materials than the $0.75 \mu \mathrm{m}{ }^{10} \mathrm{~B}$ metal lining used as the model basis [Rogers 2012]. With a thicker lining the die-away time and FOM of the ABUNCL system would be improved over the system models using $0.75 \mu \mathrm{m}{ }^{10} \mathrm{~B}$ metal linings.

The best-performing ABUNCL model with a $0.75 \mu \mathrm{m}{ }^{10} \mathrm{~B}$ metal lining, according to the studies performed, is a 95-tube model that distributes its ${ }^{10} \mathrm{~B}$-lined tubes into 5 aligned rows. The front row of tubes is $0.5-\mathrm{cm}(0.2$-inch) from the fuel cavity and the last row of tubes is $2.22-\mathrm{cm}$ 
(0.875-inch) from the trailing edge of the HDPE assembly. The inter-row tube spacing is 0.635 $\mathrm{cm}(0.25$-inch) and the spacing between tubes in each row is $0.635-\mathrm{cm}$, except in the corner blocks where the tubes are 0.318 -cm $(0.125$-inch) from each other. The efficiency of this ABUNCL model is $19.2 \%$, and the die-away time is $115 \mu \mathrm{s}$. The FOM is $3.2,24 \%$ less than that of the ${ }^{3} \mathrm{He}$-based UNCL model. Note that this is not an optimized model, but the one that has the best performance in the parameter space explored thus far. Also note that this model uses a ${ }^{10} \mathrm{~B}$ lining that agrees well with measurements of the efficiency performance of single tubes, but not necessarily with the pulse height shape or the die-away time, which was not measured.

Future work will focus on model validation of the simulated efficiency and die-away time characteristics of banks of ${ }^{10} \mathrm{~B}$-lined tubes. This work will determine if updating the model basis ${ }^{10} \mathrm{~B}$ lining is necessary to more accurately simulate the actual performance characteristics. These model validations of single banks will be applied to the optimization of full-scale ABUNCL models before the construction of a prototype. 


\section{Acknowledgements}

The United States Department of Energy Office of Nuclear Safeguards and Security (NA-241) supported this work. Pacific Northwest National Laboratory is operated for the United States Department of Energy under contract DE-AC05-76RLO 1830. Azaree Lintereur is a post Masters Research Assistant supported at Pacific Northwest National Laboratory by the Next Generation Safeguards Initiative, Office of Nuclear Safeguards and Security, National Nuclear Security Administration. Jeremy Rogers is a Masters Intern supported at Pacific Northwest Laboratory by the Next Generation Safeguards Initiative, Office of Nuclear Safeguards and Security, National Nuclear Security Administration. 


\section{References}

Croft S, A Favalli, MT Swinhoe, CD Rael. 2011. State Of The Art Monte Carlo Modeling Of Active Collar Measurements And Comparison With Experiment. Los Alamos National Laboratory. INMM Conference Record 2011.

Ely JH, ER Siciliano, MT Swinhoe. 2011. Alternatives to Helium-3 for Neutron Multiplicity Detectors. Technical Report PNNL-SA-77627, Pacific Northwest National Laboratory, Richland, Washington. 52nd INMM Meeting, Palm Desert, CA, 17-21 July 2011.

GE Reuter-Stokes. 2005. Boron-10 Proportional Counter Fact Sheet. GEA-13542A. Twinsburg, $\mathrm{OH}$.

Henzlova D, LG Evans, HO Menlove, MT Swinhoe, JB Marlow. 2010. Test Program to Compare Alternative Neutron Detectors for Potential ${ }^{3} \mathrm{He}$ Replacement for Nuclear Safeguards Applications. Los Alamos National Laboratory, Safeguards Science and Technology Group (N1) Report LA-UR-11-00098.

Henzlova D, LG Evans, HO Menlove, MT Swinhoe, V Henzl, C Rael, I Martinez, JB Marlow. 2012. Results of the Evaluation and Comparison of Alternative Neutron Detectors for Potential ${ }^{3} \mathrm{He}$ Replacement for Nuclear Safeguards Applications. Los Alamos National Laboratory Report LA-UR-12-00837.

Knoll, GF. 2000. Radiation Detection and Measurement. John Wiley \& Sons.

Kouzes RT, JH Ely, LE Erikson, WJ Kernan, AT Lintereur, ER Siciliano, DL Stephens, DC Stromswold, RM Van Ginhoven, and ML Woodring. 2010. "Neutron detection alternatives to for ${ }^{3}$ He homeland security." Nuclear Instruments and Methods in Physics Research A, 623(3):10351045.

Kouzes RT, JH Ely, AT Lintereur, and ER Siciliano. 2012. Introduction to Neutron Coincidence Counter Design Based on Boron-10. Technical Report PNNL-21090. Pacific Northwest National Laboratory, Richland, WA.

Lintereur AT, ER Siciliano, and RT Kouzes. 2012. Boron-10 Lined Proportional Counter Model Validation. Technical Report PNNL-21501. Pacific Northwest National Laboratory, Richland, WA.

PANDA. 1991. Passive Nondestructive Assay of Nuclear Materials (PANDA), Nuclear Regulatory Commission NRC-FIN-A7241. Los Alamos National Laboratory Report LA-UR-90732. Available at http://www.lanl.gov/orgs/n/n1/panda/index.shtml.

Pelowitz DB (ed.). 2011. “MCNPX User’s Manual”, Version 2.7.0. Los Alamos National Laboratory Report LA-CP-11-00438.

Menlove HO. 1981. Description and Performance Characteristics for the Neutron Coincidence Collar for the Verification of Reactor Fuel Assemblies, Los Alamos National Laboratory Report LA-8939-MS.

Menlove HO. 1987. Neutron Collar Calibration for Assay of LWR Fuel Assemblies, Los Alamos National Laboratory Report LA-10827-MS. 
Menlove HO, JE Stewart, SZ Qiao,TR Wenz, PD Verrecchia. 1990. Neutron Collar Calibration and Evaluation for Assay of L WR Fuel Assemblies Containing Burnable Neutron Absorbers, Los Alamos National Laboratory Report LA-11965-MS.

Menlove HO, D Henzlova, LG Evans, MT Swinhoe, and JB Marlow. 2011. ${ }^{3}$ He Replacement for Nuclear Safeguards Applications - an Integrated Test Program to Compare Alternative Neutron Detectors. ESARDA Bulletin 46.

Rogers JL, JH Ely, RT Kouzes, AT Lintereur, and ER Siciliano. 2012. Neutron Coincidence Counting Studies. Technical Report PNNL-21686. Pacific Northwest National Laboratory, Richland, WA.

Siciliano ER, and RT Kouzes. 2012. Boron-10 Lined Proportional Counter Wall Effects. Technical Report PNNL-21368. Pacific Northwest National Laboratory, Richland, WA.

Siciliano ER, JL Rogers, JE Schweppe, AT Lintereur, and RT Kouzes. 2012b. Uranium Neutron Coincidence Collar Model Utilizing ${ }^{3}$ He. Technical Report PNNL-21581. Pacific Northwest National Laboratory, Richland, WA. 


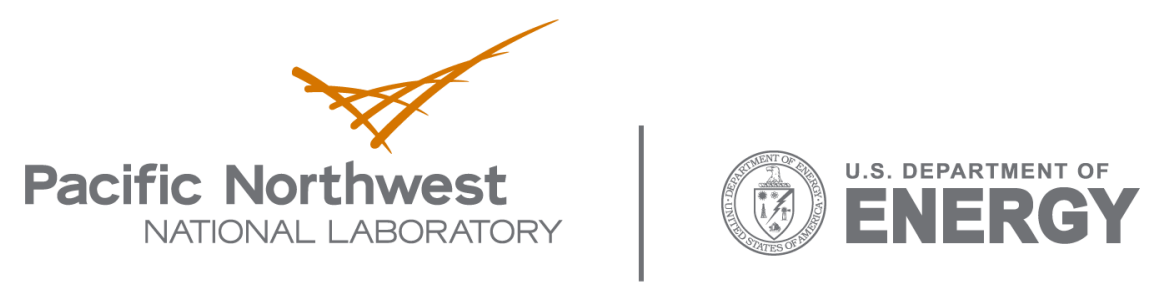

902 Battelle Boulevard

P.O. Box 999

Richland, WA 99352

1-888-375-PNNL (7665)

www.pnl.gov 